\title{
OCEANS OF HISTORY, SEAS OF CHANGE: RECENT REVISIONIST WRITING IN WESTERN LANGUAGES ABOUT CHINA AND EAST ASIAN MARITIME HISTORY DURING THE PERIOD 1500-1630
}

\section{Harriet Zurndorfer \\ Leiden Institute for Area Studies, Leiden University \\ E-mail h.zurndorfer@kpnplanet.nl}

This article focuses on recent revisionist scholarship demonstrating that China's maritime history in the period I500 to I630 is no longer a case of 'missed opportunity', a viewpoint fostered by earlier writing dominated by state-centric and land-focused models. To challenge this perspective, this study first reviews analyses demonstrating the far-reaching commercial networks between Ming China and localities in Southeast and Northeast Asia, and then considers the impact of the metaphor of Fernand Braudel's 'Asian Mediterranean' and his ideas about 'world economy' on the study of East Asian seafaring history. Secondly, this investigation reveals the dimensions of Chinese trade networks which the mid-Ming government officially sanctioned, as well as the extent to which literati from the southern provinces challenged the state's involvement in overseas commerce of trade and exchange. Finally, the article assesses how modern historians have studied late Ming maritime defense policies as security along the littoral lapsed.

Keywords: Ming dynasty; maritime East Asian history; revisionist historiography; 'Asian Mediterranean'; Chinese naval history

\section{INTRODUCTION: CHINA AND THE EAST ASIA MARITIME REGION}

In recent years scholars of maritime Asia have underlined the epistemological advantages of studying the region's history from the perspective of its frontiers, that is 'frontier' as a

This article was originally presented as a paper at the 'International Workshop Maritime East Asia in the I6th and I7th Centuries: New Sources and Perspectives', at the Sakai City Museum, Osaka, on 29 January 20I I. I thank the organizers from Osaka and Kyushu Universities, and in particular Professor Nakajima Gakusho, for their hospitality. 
relational concept, and not necessarily as a fixed geographical space. ${ }^{\mathrm{I}}$ As such, they stress this zone's permeability, its fluidity, and hybridism rather than the fixed framework of rigid boundaries demarcating one state from another. ${ }^{2}$ This view also conforms to the general trend in current historical writing to decentralize nation-state historical narratives and to pursue analyses that reveal the multilateral complex nature of cultural contact or commercial exchange in the area. Moreover, as historical scholarship turns away from EastWest dichotomous comparison, and prioritizes global relations, interest in how specific locations interacted with each other, as well as how individual indigenous entities dealt with these forces, has heightened. ${ }^{3}$

But what about China? How does its vast littoral fit into the legacies of Asian maritime history? As some authorities observe, it was China's continental frontier, and thus not its coastal zone that preoccupied dynastic governments through most of the imperial era, ${ }^{4}$ with the result that events and changes integral to both domestic development along the sea frontiers and contacts abroad never received the same amount of attention in either official histories or private documentation. 5 This lacuna may lead one to ask what facet(s) of China's heritage did connect it to other locations? One answer to this query has stressed how the Confucian intellectual tradition was a common theme that tied China to its neighbors, which meant these countries had knowledge of Chinese institutional norms and hierarchical tools. Such information, supposedly, ultimately discouraged conflict and war in coastal regions. ${ }^{6}$ But the Chinese maritime universe also stretched to large parts of Southeast Asia, including what is now Indonesia, Malaysia, Thailand, Myanmar, and the Philippines-places where Confucianism did not make an impact. Other historians emphasize China's pivotal place from the sixteenth century in a continent-wide system of (land and) water crossroads linking Northeast and Inner Asia to South Asia, Europe, and the New World.7 The problem with the 'Re-Orient' approach is that it obfuscates what political ties and economic relations were in place in East Asian maritime zones long before the Europeans entered the area to engage in trade. It also disregards what some specialists now consider an important framework for understanding East Asian relations from the early seventeenth century, when the Japanese Tokugawa government began to create a new Japan-centered model of its place in Asia. ${ }^{8}$

Such questions, trends, and historiographical developments are the subject of this article, which focuses on China's maritime history during the sixteenth and seventeenth centuries (c. I500-1630). This was a time of quickening and momentous social, economic,

I Andaya 2006; Clark 2009; on the difference between 'frontier' and 'border', see Perdue 2003, p. 6I; Perdue 2005, pp. 27-30.

2 Li 2004; Subrahmanyam I998; Wigen 2007; and more recently, Miller 2013.

3 Hamashita 2004.

4 Fitzpatrick I992; Hong 2010.

5 Wilson 2009, p. 240.

6 Rozman I99I. In contrast, Wang 20I I emphasizes how the Ming government was willing to use military force to keep vassal states in line.

7 Frank 1998; for critique of the 'inter-regional interdependencies' as stressed by Frank, see Arrighi et al. 2003, pp. 7-8.

8 Wang 2008; Rawski 2010; Lee I999; see also the important work (in translation) by Asano 2005. 
cultural, and political change in the region and in the country. We begin our study with an overview of how current research has transformed the traditional 'tribute' concept of Chinese foreign relations, and has contemplated the relevance of the French historian Fernand Braudel's 'Mediterranean' for the study of Asian maritime history. These topics, as we will show from an analysis of recent publications, signify a certain paradigm shift in which China's maritime history is no longer a case of 'missed opportunity' or 'minor tradition'. ${ }^{9}$ Moreover, this scholarship has come to abandon the view that the arrival of Western powers (Portuguese, Spanish, and Dutch) in Asia marked a sharp disjuncture in the East Asian maritime world. Now it is more common for historians to identify ways in which these foreigners had to conform to local practices in an arena of intensifying regional interaction. As one Asia specialist noted, "much of the activity we have parochially thought of as 'the expansion of Europe' was the European participation in the expansion of East Asia." то This observation brings us to the second major focus of our study: how historians now assess China's maritime trade and naval defense policies in the sixteenth and early seventeenth centuries.

\section{TRIBUTARY TRADE, THE 'NEW THALASSOLOGY', AND THE 'BRAUDELIAN EASTERN MEDITERRANEAN'}

The maritime approach to Chinese history vies with the long-dominant state-centric and land-focused scholarship that prioritized China and its role in the tributary trade system,

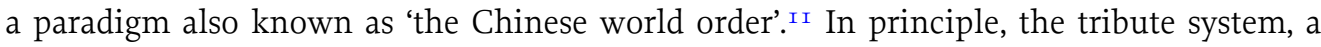
very early legacy of the Han dynasty (2O2 BCE-CE 220), required foreign rulers to send embassies to China to bear tribute (usually local products unavailable elsewhere) and to demonstrate their recognition of Chinese cultural superiority by their performing the ritual of koutou 磕頭, kneeling three times, each time bowing their head to the ground thrice. In turn, the emperor offered emissaries gifts of equal or greater value. ${ }^{12}$ Moreover, this model dictates that China's trade relations were conducted almost exclusively within the confines of this system. In reality, the tributary system, as primary Chinese historical records clearly show, was not so stringent and comprehensive; for example, during the Song (960-I279) and Yuan (I279-I368) eras, tribute trade and diplomacy were deeply intertwined and extensive overseas commerce legitimized. ${ }^{\text {I3 }}$ Such international contact

9 See the useful but somewhat dated review essays by Gardella I985; Chang I992; and Lai I995. Also, somewhat passé is the article by Wills 1993 which sketches 'responses' of Asian peoples to European encroachment in the maritime realm.

Io Observed by the Japan historian Marius Jansen, and cited by Swope 2009, p. 48.

I I The Harvard historian John K. Fairbank made famous this model in a I 968 book by that name. On the origins of Fairbank's ideas about the 'Chinese world order' under the influence of the prominent historian Jiang Tingfu [T. F. Tsiang] (I895-I965), see Fairbank’s autobiography (I982, pp. 85-93), Tsiang I936; and also Zurndorfer 2004a. See also Zhang 2009 which offers a highly critical analysis of Fairbank's sinocentric 'world order' model.

I 2 Hevia I995, pp. I24, I32-33 observes that in the tributary model, inequality was the basis for all relations between the two units.

I3 On the formation of Chinese maritime networks into Southern Asia I200-I450, see Sen 2006. On the Hokkien traders in Southeast Asia during the Song era, see Chang I998. See also the important article by Soon 2008 on Chinese maritime networks in Southeast Asia in the same period. Heng 2013 analyses the 
also affected China's own development. In the Song era, the Fujian port of Quanzhou 泉州 gained the reputation of being one of the world's great cosmopolitan centers. ${ }^{\mathrm{I} 4}$ Modern investigations have turned up the remains of gravestones in Arabic, Persian, Syriac, and Latin and also the ruins of Hindu and Muslim religious sites. ${ }^{15}$ The region prospered enormously as local elites gravitated toward commercial opportunities in Southeast Asia. ${ }^{16}$

In the Ming dynasty (I368-I644) a more restrictive trade system was in use, with tribute missions the principal form of contact between China and other polities, of which Korea, Japan, and the Ryūkyū Islands were the most important. The maritime tribute missions entered China either at Guangzhou 廣州 (Southeast Asian states), Quanzhou (the Ryūkyū Islands), or Ningbo 寧波 (Korea and Japan). There also existed a kind of informal arrangement whereby foreigners (whose home areas did have tribute relations with China) could anchor in Chinese ports through a licensing system, buy and sell goods, but not settle permanently. Thus, from the fourteenth century onward, ships from a number of Asian lands, including Java, Borneo, Sumatra, Malacca, Sri Lanka, Cochin, and Calicut enjoyed the privileges of such commerce. ${ }^{17}$ In this same period, China also sent tribute missions to other realms "to grant investiture to foreign kings." ${ }^{8}$ On the other hand, maritime prohibitions (haijin 海禁), introduced in I37 I by the first Ming emperor who sought to 'immobilize the realm', forbade Chinese persons from traveling abroad without authorization, building ocean-going junks, trading with foreigners (in China), and colluding with smugglers. Those caught were liable to capital punishment and their families to banishment. ${ }^{\text {I9 }}$ One modern scholar has suggested that the restrictive maritime trade policy aimed to contain the maritime economy and China's seagoing population in order to keep their dynamism from superseding the dynasty's other strategic and economic priorities. ${ }^{20}$ In any case, one of the long-term effects of these bans was the consolidation of existing trade networks throughout the region, and the increasing importance of Chinese living outside China. ${ }^{21}$ According to Wang Gungwu, the prohibitions insured those Chinese living in foreign locales had to prolong their stay indefinitely, with the result they began to form permanent communities outside China from where they continued to engage in overseas commerce. ${ }^{22}$

But some Chinese native traders did defy the Ming injunctions and engage in overseas commerce from China. As indicated by Roderich Ptak, Chinese merchants during the fifteenth century maintained an extensive regional water network which was comprised of

integration of the economic interaction between China and the Malay region from the tenth to the fourteenth centuries.

Clark 200I.

Clark I995; see Chaffee 2006 on the complex links between Chinese local communities and Muslim traders.

So 2000.

Lee I999, p. I7; Kang 20I0, p. II2; Wilson 2009, p. 255.

Tsai I996, pp. I4I-64.

Brook I998, p. I9; Li 20I0, pp. 3-4.

Wilson 2009, p. 245.

Kang 20IO, p. II 2.

Wang I99I, p. 85. Chang I99I claims the existence from the fifteenth century of a Chinese diaspora stretching from Malacca to Japan. On the distinctive Chinese communities in Japan, see Asano 2005, pp. I96-97. 
two parts: a western route from the port of Guangzhou linking Champa to places on the Malay peninsula and northern Java (Surabya, Gresik, and Tuban); and an eastern route from Quanzhou connecting the Ryūkyū Islands, the Philippines, Sulu, and Borneo..23 Most of the inter-island trade was in Indonesian vessels, but the China connection from Champa or Siam and the Ryūkyūs was sailed by Chinese from Fujian province. Trade goods came from as far away as the Sunda islands and Timor, including sandalwood, tortoise-shell, shark fins, pepper, and spices. These items reached China either illegally or as tribute trade accompanying official missions, including those from Vietnam and the Ryūkyūs. Chinese items imported into Southeast Asia included firearms and ceramics. ${ }^{24}$ In the fifteenth century the number of Chinese involved in the trading networks supplying Java increased, ${ }^{25}$ while the Chinese presence in Melaka (Malacca) intensified. ${ }^{26}$ Also, the numbers of Chinese settlements in Cambodia, Siam, and the Philippines rose during the latter decades of the fifteenth century. ${ }^{27}$

The China-Ryūkyū connection was especially significant for Fujian, and demonstrates how illegal trade could be camouflaged via the tribute system. ${ }^{28}$ From I 385 to I435, the Ming government provided ships and trained sailors to the Ryūkyūs to help maintain the island kingdom's regular yearly tribute mission. After I435, the Chinese authorities no longer granted ships, but did allow the Ryūkyūans to build them at their own cost in Fujian and to continue to employ Chinese sailors. At this point the Ryūkyū kingdom traded far and wide in the East Asian seas, sailing to Japan, Korea, Vietnam, Siam, Melaka, Sunda, and Palembang to distribute Chinese products which it had obtained via the tribute mission. ${ }^{29}$ On their return to China, they brought horses and sulfur (used in traditional medicine and in making gunpowder), along with traded goods originating in Southeast Asia. It would seem that the China-Ryūkyū tribute trade became the most active network for Sino-foreign exchange before the sixteenth century. Moreover, the Ryūkyū kingdom emerged in the fifteenth century as a major transshipment center where international traders from all over East Asia congregated to exchange cargoes. ${ }^{30}$ Although it is not entirely clear why by the I470s the Ryūkyū ships calling on Fujian decreased while Ryūkyū activities around Guangzhou increased, the kingdom's transshipment function disappeared by the early sixteenth century, at which point smuggling along the Chinese littoral expanded to such intensity that it displaced ordinary tribute trade almost entirely. ${ }^{3 \mathrm{I}}$

Ptak I998a, pp. I57-9I.

Wade 2008 provides an excellent synopsis of both land and water trade networks between China and Southeast Asia during the fifteenth century.

Stuart-Fox 2003, p. 98.

Lockard 20Io, pp. 228-32; Hall 2006, pp. 466-70.

Stuart-Fox 2003, p. 98. For further information on Ming China's engagement with Southeast Asia, see Wade and Sun 2010.

Ptak 2003a, p. I5. For more information on the Ryūkyū Islands in East Asian maritime history, see Kreiner $200 I$.

Chang Pin-tsun I990, p. 67.

Chang I990, p. 67; Ptak 2003a, pp. IO-I I. See also Hamashita 2008a, pp. 57-84, and Hamashita 20I I, pp. I I2-I 3.

Chang I990, p. 67. 
The multifarious dimensions of the tribute system are also discussed by Hamashita Takeshi 濱下 武志, whose work in part is now published in English. ${ }^{22}$ He has argued the extent to which tribute was in fact at once both a political and cultural tool and an economic and financial mechanism. In other words, the tribute system did not function in one single dimension. ${ }^{33}$ According to his schema, a country may have paid tribute to China while it expected tribute from its neighbors. In this way, tributary practices acted as a loose system of political integration embracing maritime Asia, from the Northeast to the East, and from Southeast Asia to Oceania. Consequently, and as written records confirm, Vietnam demanded tribute from Laos, and Korea, while a tributary to China, also sent tribute missions to Japan. ${ }^{34}$ This network of relationships also had an important economic side. Reviewing Asia's trade history since the sixteenth century, Hamashita noted that the entire complex tribute trade formation was determined by the price structure of China, and that the tribute trade zone formed an integrated 'silver zone' in which silver was used as the medium of trade settlement. 35 In other words, as he writes, one should envision "Asian history as the history of a unified system characterized by internal tribute/tribute trade relations, with China at the center." 36

Hamashita's approach accentuates other recent scholarship that has prioritized the world's oceans and seas as important foci of historical inquiry. ${ }^{37}$ Such analyses view ocean and sea basins no longer as barriers to communication or empty spaces on the way to legendary continents, but rather as configurations of interaction in which commercial, biological, and cultural exchange among peoples of different societies are paramount-a focus that other frameworks, and in particular national or diplomatic histories, often obscure. ${ }^{38}$ While large-scale approaches to the maritime past are not entirely new-one thinks of Fernand Braudel's vision of the Mediterranean as a meeting point of integration-contemporary scholarship has recast the French historian's model into "the new thalassology" which emphasizes the systematic study of the relationships of wide-scale contacts and exchanges. ${ }^{39}$ Thus, to date, some of the world's other great bodies of water, including the Atlantic, the Pacific, and the Indian Oceans, have become the subject of scholarly analyses aimed at gaining greater insight into the peculiarities of local and regional boundaries, as well as the related processes of social and economic assimilation

39

Grove and Selden 2008, pp. I-II.

Hamashita 2008b, pp. I2-26.

Hamashita I994, pp. II3-35. See also Hamashita I997. On the fifteenth century, 'Korean tribute system' and a 'Korean world order', see Robinson 2000.

Hamashita 2008b, pp. I7-20.

Hamashita I994, p. 92. Gunn 20I I aims to place Southeast Asia at the center.

Wigen 2007; Bentley I999.

Among the first publications to regard the significance of ocean currents and wind patterns for understanding history was J. H. Parry I974. See also Lewis and Wigen 1997.

Braudel's two-volume study of the Mediterranean (I976 translation) and his three-volume analysis of civilization and capitalism (I982-84 translation) are the relevant publications here. In 2006, The American Historical Review (AHR) featured a special forum with articles focused on the history of water bodies, including the Mediterranean Sea, and the Atlantic and Pacific Oceans. See Wigen 2006. The term 'thalassology' originates in the ancient Greek term thalassa, meaning the sea. 
and differentiation. ${ }^{\circ}$ This new scholarship embraces well-known conceptual realms of historical globalization - diasporas, trade empires, commodity and currency flows, technology transmission, ideas and religion, and not least, war-and as such, merges the field of world history with that of maritime history. ${ }^{4}$

However, conventional maritime history which encompasses a broad range of topics, including navigation techniques, ship design, deep sea exploration, mapping, international law, and even seaside resorts, originated in social analyses initially developed to comprehend land-based societies, while most of the world's oceans lie outside of nations and national histories. ${ }^{42}$ Nevertheless, this dichotomy should not prevent one from appreciating how ocean and sea spaces have in history served multiple functions, such as resource areas, transportation surfaces, battlegrounds, buffer zones, and even as 'heterotopia', termed by Michel Foucault to mean a space for the creation of experimentation and alternate social models. ${ }^{43}$ One may also consider seas and oceans as depositories of histories of the myriad events that entwined humankind with the sea, ${ }^{44}$ both those of great renown and those that were never written down but only passed orally through generations, and which are now the subject of archaeological investigations that provide a wealth of data about China and its neighbors. 45 Thus, the historical significance of ocean and sea regions is their function as sites where local, regional, and global forces interact, either on a systematic or irregular basis.

The idea of viewing oceans and seas as major channels promoting communication also has relevance to the study of East Asian maritime history. One may already trace the appeal of such a 'Mediterranean' to Southeast Asian specialists long before Braudel's publication La Méditerranée appeared in print. In the mid-twentieth century historians were beginning to write about the significance of Southeast Asia not in terms of its colonial encounter, but with regard to its own self-generated dynamism in which the seas around it were the key to its prosperity.46 Georges Coedès (I886-I969), Director of the École Française d'Extrême-Orient from I929 to I947, conveyed in a I944 publication that Southeast Asia was "a veritable Mediterranean, formed by the China Sea, the Gulf of Siam and the Java Sea ..." and stressed the unity of this enclosed space. ${ }^{47}$ Coedès's ideas became the framework of an influential essay by another well-known Southeast Asia specialist, Oliver Wolters, who envisioned the many seas of this locale as a mediator of historical experiences shared between disparate places. ${ }^{48}$ Since the I990s, a number of scholars have

On the 'new thalassaology' and Indian Ocean studies, see Vink 2007, and Tagliacozzo I984. See also Clark 2006. For a general introduction to models for historicizing the maritime realm, see Steinberg 200I, pp. $42-43$.

See the volumes by Finamore 2004; Klein and Mackenthun 2004; and Miller 2013.

Wigen 2007, p. 17.

Steinberg 200I, pp. 33, 38.

Fernández-Armesto 2004. Manguin I993.

Van Leur 1955. On van Leur and his ideas, see Vogel 1998.

Quoted in Sutherland 2003, p. I3.

Wolters I982. See also Wolters's I999 revision of this study which is reviewed by Evans 2002. 
extended the Mediterranean analogy to include the seas between China and Southeast Asia, which they consider 'Braudelian zones' of busy and regular maritime interaction, linking regions of separate cultures and traditions into a common space. During that decade the Southeast Asia historian Denys S. Lombard, author of the magisterial three-volume 'Annalist' study Le carrefour javanais: Essai d'histoire globale, 49 and Roderich Ptak began a collaboration to create a large-scale project that would compare the European Mediterranean and maritime Southeast Asia on both conceptual and factional levels. ${ }^{50}$

After Lombard's untimely death in I998, Ptak pursued this enterprise in other directions, and extended the Frenchman's 'Southeast Mediterranean' further afield to include the entire South China Sea, with the coasts of Guangdong and Fujian, Hainan Island, and Taiwan. ${ }^{5}$ He proposed that these regions formed part of one and the same system that extended to Sumatra, the Gulf of Siam, as well as the many seas and islands of what is now modern Indonesia..$^{2}$ As a sinologist, Ptak was well aware that China historians looked predominantly from the land to the sea, but for him the alternative focus, that is to regard the coast from the sea, juxtaposed the significance of littoral. Thus, he suggested the important port city of Quanzhou might be viewed in at least three different ways. First, according to the mainstream view, it was a critical connection to the mountainous Jiangxi hinterland and the interior of China during the Song-Yuan era (960-1368) and that its seabound trade was an exterior factor to its well-being. The second vision presumes Quanzhou was integral to greater maritime Asia and that the locale's contacts to Luzon, Batuan, and Srivijaya were essential to both its own prosperity and that of South China.53 The third perspective, Ptak noted, underlined Quanzhou's location between two worlds, or 'systems', a vital part of both China and 'Greater Southeast Asia'. Ptak's quest to create an integrated East Asian Mediterranean project saw fruition in 2002, when he gained funding to organize a series of conferences on various dimensions of this theme, and in 2005, the first conference volume was published. ${ }^{54}$ The published compilations have attempted to demonstrate how an 'East Asia Mediterranean' in which the East China Sea, the Yellow Sea, the southern section of the Japanese Sea, and parts of the South China Sea, may be viewed as one zone that serves as a focal point for determining connections between them. 55

Lombard I990; and for a penetrating review of this publication, see Subrahmanyam I994.

On the collaboration, see Ptak I998b; see also Lombard I995, and I998; Guillot and Ptak I998, p. vii.

On Hainan, see Ptak and Lombard-Salmon $200 \mathrm{I}$.

Ptak 200ra. See also Ptak 200rb.

On this view, see So 2000; Clark I99I.

The project, financed by the Volkswagen Foundation, ended in 2009, and resulted in a series of conference volumes under the editorship of Angela Schottenhammer. For further information, see the project's website: www.eamh.net/index.html To date the project has received mixed reviews which accent the volumes' "narrow focus on traditional Chinese perceptions of maritime space", and the lack of coherency, as well as no indices in any of the books. See reviews in the International Journal of Maritime History I 8.I (2006), pp. 388-89; I9.I (2007), pp. 352-53; I9.2 (2007), pp. 439-40; 2I.I (2009), pp. 352-53; and the Journal of the Humanities and Social Sciences of Southeast Asia I67.I (20II), pp. I23-25. The relevant volumes are Schottenhammer 2005; 2007; and 2008; Schottenhammer and Ptak 2006. More successful with the use of the Asian Mediterranean metaphor in terms of integrating detail and long-term narrative is the study of Gipouloux (2009; 20II). 
But the Mediterranean analogy also has its skeptics, and specialists from both China and Southeast Asia have contributed critiques about the extent of its usefulness. Significantly, the doyen of Nanyang 南洋 (South China Sea) studies, Wang Gungwu, raises doubts about the unity of this Eastern Mediterranean concept. ${ }^{6}$ He points out that in Asia until the tenth century, there were really in effect two 'Mediterraneans': first, the space of the southern seas which was strongly linked to the Indian Ocean but also too fragmented to transform itself into a territorial power; and second, the Donghai 東海 (East China sea region) of China, Korea, and Japan. ${ }^{77}$ Here Confucian thought and Mahayana Buddhism as well as similar agricultural and manufacturing techniques bonded these locations into one cultural zone. Wang also points out that, in contrast, Indian Ocean cultures in the South China Sea prevailed and influenced the art and architecture, languages and scripts, gods, rituals, music and dance of the region..$^{8}$ He also argues that despite Kubilai Khan's fullscale naval operations, and the voyages of Zheng He 鄭和 (I37 I-c. I433) in the early fifteenth century, it was China's power on land that mattered most in inter-state relations. ${ }^{59}$ Similarly, R. Bin Wong doubts the efficacy of the 'Eastern Mediterranean' model: he suggests that the seas along China's littoral were much more open and at the same time firmly linked to China's continental empire, which in the long run meant that "it was less likely for the connections between power and profit that most strongly emerged in the Mediterranean to emerge for the Chinese and their trading partners."

Finally, it is of interest to mention Braudel's own misinterpretation of China's economic advancement, including that derived from maritime commerce from the sixteenth through eighteenth centuries. Because he did not utilize scholarship available to him during the I970s when he wrote his tri-part study Civilisation matérielle, there are major gaps and misinformation in his discussions of China in these volumes. As Mark Elvin points out in a scintillating evaluation of this work, Braudel dismisses the extent to which coastal trade impacted the Chinese economy and attributes the 'overbearing state' responsible for hindering the development of capitalism there. ${ }^{6 I}$

From the perspective of Southeast Asia, a number of historians have also expressed their doubts about the analogy. Heather Sutherland, while acknowledging how fellow area specialists might appreciate the conceptual possibilities of the 'Mediterranean approach' to

56 Wang 2008.

57 Wang 2008, pp. I5-I6. On the historical 'unity' of China, Korea, and Japan, see Hong 2010 which also focuses on tribute relations between China and nomadic groups on its northern borders; on early trade relations between China, Japan, and Korea, see Von Verschuer 2006, which is particularly useful for understanding knowledge and skill diffusion in the fields of sericulture, ceramics, and figurative art among the three countries.

58 Wang 2008, p. I6.

59 Wang 2008, p. I7.

60 Wong 2003, p. I2. An earlier version of the same essay appeared in French in 200I. Wong's views here follow those expressed in Wills I979, pp. 208-Io. See also Wong 2004.

6I Elvin 2002, pp. 246-5I. In consultation with the French sinologist Jacques Gernet, Elvin (2002, p. 232 n. I9) suggests that Braudel's friendship with the China scholar Étienne Balazs, who was obsessed with a hatred of the Chinese bureaucratic system which he likened to Nazism, may have played a role here. See also Zurndorfer 2004b. Another critic of Braudel, the anthropologist Jack Goody disapproves of his 'unchanging' (and by implication, 'essentialist') views of Ming China's economic development. See Goody 2006, pp. I802II. 
this region of multiple independent states and numerous ethnicities, also questions its viability. She stresses that "knowledge of early modern Southeast Asia is fragmentary, and little consensus exists regarding the fundamentals of social structure, economic organization and political change." ${ }^{2}$ Sutherland is also troubled about the problem of casting "an essentialised China" into "a multi-webbed Braudelian Southeast Asia," which will not lead to proper understanding of China in that location. ${ }^{63}$ Another scholar, Jennifer Gaynor, argues that Braudel's Mediterranean model encompasses an enclosed basin which does not apply to the much more open-ended waters of Southeast Asia. ${ }^{64}$

Such concerns over the feasibility of the Mediterranean analogy should not present theoretical barriers to our study here as we hope to demonstrate how the Braudelian 'world economy' does have relevance to sixteenth-century China, a time of both increasing economic growth and military innovation in the country. The findings of recent publications about Ming overseas trade policy and defense strategies indicate how the Chinese state functioned as a sea power (in terms of human and material resources as well as technological acumen), although the coastal frontiers were never a consistent government priority. What also emerges from these studies is an interest in how the two foci of economy and military security become intertwined in Chinese maritime history during the sixteenth and early seventeenth centuries.

\section{CHINA AND THE SOUTH SEA WORLD ECONOMY}

One of the first problems encountered in published writing about Chinese maritime history during the sixteenth and early seventeenth centuries is the relative lack of attention paid to this period in comparison with that focused on the relatively short episode of Zheng He's voyages (1405-I433) under the Yongle 永樂 emperor. ${ }^{65}$ Although it may be true that the scale and the audacity of these expeditions dwarf all subsequent manifestations of Chinese maritime power, nevertheless in the long run, it was China's integration into the 'South Sea world economy' that would prove more significant. ${ }^{66}$ As Timothy Brook argues, the Zheng He voyages did not bring an end to Chinese trading in the South China Sea-but, rather, became a turning point in the tribute trade system. "If the tribute system provides the framework for understanding these voyages..., it also helps to explain their cancellation, for once it was fully functioning, the system did not require the extravagant return missions that Yongle had been sending." ${ }^{67}$ But for many other scholars, the early Ming naval exploits under the eunuch official who led "great armadas of hundreds of

62 Sutherland 2003, p. I8. The Southeast Asia specialist Craig Lockard questions the limitations of monsoon winds which, in contrast to the Mediterranean year round shipping, allowed for only six-month sailing seasons in Southeast and East Asia. See Lockard 2010, p. 220.

63 Sutherland 2003, p. I4.

64 Gaynor 2007.

65 There is a tremendous amount of literature on Zheng He; see the comprehensive study by Levathes I994; and also Dreyer 2007 which is the best publication to date on the man and his voyages. The well-known and controversial volume by Menzies 2003 stimulated further discussion about the Ming navigator. See Findlay 2004, and Robinson 2010. Also Prazniak 2010 is of interest.

66 Brook 20Io, pp. 226-27.

67 Brook 20IO, p. $22 \mathrm{I}$. 
ships and tens of thousands of men as far as the coast of East Africa in the early fifteenth century" was an aberration of a regime that "turned its back on the sea." 68 Even Joseph Needham, as the late Frederic Wakeman observed, subscribed to this standpointNeedham wrote that with the end of Zheng He's voyages, "[China's] great naval possibilities had been done to death." ${ }^{69}$ Furthermore, in their view the series of stringent maritime bans in effect until 1567 seem to epitomize the Ming disdain for the sea and foreign trade. ${ }^{70}$ John Wills, Jr. in an influential essay published in I979, claimed that the oceans remained peripheral during the Ming because of the vast and dangerous seas around China and the few significant trade opportunities to be had prior to the sixteenth century. ${ }^{71}$

Aside from underestimating the impact of flourishing trading networks supervised by Chinese in the East Asia diaspora, the difficulty of these latter perceptions is that they write off the political and economic strengths of the Ming state. In rebuttal to those who would dismiss Ming maritime power, Brook has provided an entirely different scenario. According to him, as long as the Ming authorities were able to deny foreigners access to China's domestic market, and the economy flourished, producing "goods of sufficient quality and reasonable price," 72 the tribute trade system served its purpose. Also, he writes, as China's commercial economy expanded in the sixteenth century, "the border closure policy" guaranteed China's continuing centrality in a network of regular exchange linking it to more distant zones and the growing value of the goods circulated, while "an autonomous division of labor [within China] assured resilience in the face of alterations." 73 What developed in the South China Sea then was a network of multilateral exchange, among merchants whose states submitted tribute trade to the Ming, "that was sufficiently robust to constitute what may be called a 'world economy'."74 This 'world economy', according to Brook, does not mean the economy of the entire world, but

a large region which, through regular networks of exchange, has achieved a high level of economic integration and sustains a relatively autonomous division of labor internally. This relative autonomy enables a world-economy to constitute its own 'world', self-sustaining and resilient in the face of alterations, but capable of linking to more distant zones as the value of the goods it circulates grows. ${ }^{75}$

Wilson 2009, p. 238 aims to revise this traditional view of Chinese maritime history. One of the best examples of the school 'maritime history reached its peak in the Song dynasty' is Deng I997; other recent scholarship has challenged accounts originating in the Mingshi 明史, the official history of the Ming dynasty, about the size of Zheng He's ships. See Wake 2004.

Wakeman I993, p. I3.

One of the first studies in a Western language about these regulations was Wiethoff I969.

Wills i979, pp. 208-10. Brook 20I0, p. 226.

Brook 2010, p. 227. Elsewhere Brook 2013a, pp. 23-24 has demonstrated the contradictions between trade and diplomacy.

Brook 20I0, p. 226. 
Thus, we see here how Brook invokes Braudel's vision of 'world economy' without drawing upon European involvement in China's maritime economic history. The irony of this historiography is that Braudel's conceptualization proves useful, although the French historian's own understanding of the dynamics of the Chinese maritime economy during the Ming was rather limited.

The fifteenth century was a time of ever-growing affluence in China. ${ }^{76}$ It was then that the 'bucolic dream' of the first Ming emperor, Zhu Yuanzhang 朱元璋 (r. I368-I398), to create a self-sustaining economy in which closed communities of farmers grew their own food and crafted for themselves all the goods (such as clothing) that they needed, came to an end.77 As economic surpluses led to commodity production, inter-provincial trading, and a widespread money economy, there was a fundamental shift in the economic geography of China. The silk and porcelain produced in locations far away from the ports in Fujian or Guangdong had to be transported (overland) and the state provided the infrastructure by which these commodities and others (such as salt) circulated. Thus, the role of the government was to insure that the canals and roads by which trade flowed remained functional: "the Ming state provided a push to movements of people and goods." 78

The fundamental flaw in the system at this point was that, for financing this service, the Ming authorities continued to rely on the revenue collected from the agricultural sector, which ultimately proved insufficient. What funds the state could collect from this source were committed to the upkeep of the imperial family as well as bureaucratic expenses and military ground troop costs. And thus with limited financial resources, as Andrew Wilson argues, the state did not have the wherewithal to become more involved in maritime affairs: "the Ming chose to try to keep overseas trade at a low enough level that would neither strain government spending nor present a serious security problem."79 Perdue contends that like the Ming dynasty's 'defensive' border policies in the northwest, the government pursued a maritime equivalent of the Great Wall: the maritime bans were designed to segregate mobile seafarers from sedentary coastal communities. ${ }^{80}$ In any event, despite the growing wealth both domestic and foreign commerce created during the fifteenth century, it would seem that the economy remained fundamentally parochial and the state averse to rescinding the maritime prohibitions. ${ }^{8 \mathrm{I}}$

But by the sixteenth century, the tensions between those who relied on overseas commerce for their livelihood and the Ming authorities, bent on upholding the maritime bans, reached an all-time high. As the commercialization and monetization of China's economy intensified, the thrust to engage in illegal trade and thus defy the prohibitions became ever more appealing. The result was endemic smuggling along the coast, and eventually plundering and the destruction of local property. A wave of piracy hit the Chinese coast from

76 Brook 1998 categorizes this period as China's 'middle century' or 'spring'.

77 Brook I998, p. I9; see also Zurndorfer 2002.

78 Brook I998, p. Iо.

79 Wilson 2009, p. 255.

80 Perdue 2005, pp. 38-39.

8I There were other problems the government faced during the second half of the fifteenth century, including plagues, famine, and extreme weather conditions. See Atwell 2002. This may explain why the Ming government began then to scale down the frequency and the number of foreign tribute missions it would accept. 
I504 to I524, but it was the later storm of predations beginning in I 548 which made the greatest impact on East Asian maritime relations. ${ }^{82}$ In between these two outbreaks, violence along the littoral continued while attempts by local people and some administrators to create an infrastructure for maritime trade floundered. ${ }^{83}$ For example, efforts to elevate the administrative status of Yuegang 月港 (Moon Harbor), the seaport of Fujian's Zhangzhou 漳州 that now handled the bulk of the 'unofficial' maritime trade between China and Southeast Asia, failed due to struggles at court over who would control coastal revenues. ${ }^{84}$ These disagreements reflect yet another major weakness in the Ming governmental system: those officials who had influence and power at court were also those who originated from the southeast coastal regions, and thus they had the most to lose from an interventionist and rapacious state. ${ }^{85}$ It may be surmised that it was their influence that secured the imposition by the Ministry of Justice in I 525 of an injunction against twomasted ships and even a ban on fishing boats in I 55 I. ${ }^{86}$

In a penetrating investigation of these Ming seafaring policies and pirate incursions, Robert J. Antony argues in his 2003 book Like Froth Floating on the Sea that it was the contradictions within China's maritime society which engendered conditions of conflict, violence, and predation. ${ }^{87}$ Thus, according to his view, Ming commercialization created not only prosperity but also havoc for those persons without easy access to more legitimate forms of trade. Moreover, South China's geography with its infinite coves, inlets, and islands provided ideal physical conditions for piracy. Consequently, poor fisher folk who lived there could rely on pirate ships whenever trading, fishing, or farming might not sustain them. Antony's thesis, that piracy arose not so much as the result of the widespread immiseration of Chinese society but, rather, as the consequence of the stresses that overall prosperity had placed on the more marginal elements of the seafaring society, has relevance to other developments occurring around this time. The pirate attacks, according to the study of Zheng Zhenman, weakened the territorial control southern Fujianese local lineages might have once held over their members and their property. ${ }^{88}$ But at the same time, he suggests, the incursions also strengthened the initiatives by individuals there to construct forts and organize local defensive militia, which in the long term "encouraged a social atmosphere in which bravery and ferocity were highly esteemed." 99

82 Brook 20Io, p. 223 attributes the earlier rise of piracy and the economic regional slump that hit the Chinese coast to the aggressive actions of the Portuguese who arrived in the South China Sea area in the I5Ios. For an economic analysis of the piracy attacks, see Kung and Ma 2014.

83 Geiss I988, pp. 490-94.

84 Brook 20Io, p. 42. See also Chang Pin-tsun 2006, p. I8 on Fujian people's attempts to persuade government authorities to relax the bans by allowing fishing and the harvesting of aquatic products.

85 Wilson 2009, p. 24I; Wakeman I993, p. I4, n.I3.

86 Andrade 2004, p. 4I8, n. 7.

87 Antony 2003, p. II.

88 Zheng 200I, pp. 20I-I2.

89 Zheng 200I, p. 2I 2. It is also interesting to note that modern literary scholars have shown that in the second half of the sixteenth century many Chinese writers began to attach great importance to the notion of xia (chivalry), and that they celebrated the values of 'loyalty, gallantry, manly conduct, and heroism' in fiction narratives. Also, it was about this time that China's most famous novel of noble warriors, Shuihu zhuan 水 澈傳 (Water Margin) was composed. See Barr I997. 
Violence between feuding lineages also increased. In general, the combined and linked roles of lineage organizations, which were particularly pervasive in both Fujian and Guangdong, in trade networks, overseas Chinese residential communities, and local defense institutions, are not well understood-for example how did powerful lineage organizations circumvent trade prohibitions? —and warrant further investigation. ${ }^{9}$

This second wave of piracy, starting in I548 and lasting through the I550s and I560s, was transnational. It would seem, as Antony posits, that the maritime bans instead of curbing illegal activities actually encouraged them, and thus criminalized large segments of the coastal population. ${ }^{9 \mathrm{I}}$ Local people banded together with foreigners, including Japanese, Malaccan, Siamese, and later Portuguese, Spanish, and even African adventurers-who collectively became known as wokou 倭寇 (Japanese pirates) — and disturbed the peace by robbing travelers and looting houses and tombs all along the littoral from Jiangsu and Zhejiang provinces to the seas and coasts of Fujian and Guangdong. Despite the international membership of these groups, Chinese writings of the time invariably focus on the Japanese participants who, as the modern scholar Wang Yong shows, had become very undesirable persons..$^{22}$ The leading brigands mixed trade with smuggling and pillaging, organized large fleets, and established bases for attack on islands along China's sea coast.93 The wokou were also known to take captives and sell them as slaves either in Japan or among international traders. ${ }^{94}$ Many of these 'pirate chiefs' had powerful patrons and safe bases in Kyushu (Japan) where they lived like 'kings' surrounded in luxury with 'trains of Japanese myrmidons'. 95 One of the striking features of this surge of piracy was that several of its most powerful leaders had once been legitimate Chinese merchants. This situation begs the question: why did the Ming government not acquiesce at this point and give up the maritime prohibitions? Again, the answer may lie in the fact that many pirate groups sought protection with influential families and local administrators, and thus it would not have been in the interest of these officials to have their affiliations made known..$^{96}$ Also, it may be the case, as Wilson suggests, that Ming literati who documented events of this period, in both private and official histories, were themselves hostile to military expenditure, overseas adventurism, and state involvement in the maritime economy, and thus, their writings “... downplay or deride the scale and nature of the Ming state's interest in overseas trade and naval issues.”97

Although the review article about family organizations in Southeast China and Southeast Asia by Kwee 2007 provides a listing of publications related to this matter, it does not offer any theoretical insights for further research on this topic. Ptak I994, pp. 4I-43 discusses briefly the contacts between overseas Chinese entrepreneurs and their relatives back in China. See also Kuhn 1997.

Antony 2003, p. 23. Chin 2010 argues the piracy attacks launched China into a new kind of maritime economy outside Ming government control. As Lim 20 ro demonstrates, the raids also influenced lineage formation in areas along the littoral.

Wang 2002.

Antony 2003, pp. 23-25.

Asano 2005, p. I95.

Elisonas I99I, p. 260; Asano 2005, p. I88.

Li 2010: Chapter 5 discusses pre-I567 'pro' and 'anti' trade factions of officials.

Wilson 2009, p. 24I. 
By the I570s the wokou crisis subsided. When a new emperor came to the throne in I567, the maritime prohibitions (except for Japan) were lifted. "Overnight, pirates became merchants, contraband goods became export commodities, and clandestine operations became a business network" linking other locations to Fujian's two major commercial cities, Quanzhou and Zhangzhou..$^{98}$ With the initiation of an 'open seas' policy that allowed Chinese merchants to sail abroad for trade on the basis of a permit system, smuggling and piracy decreased. ${ }^{99}$ Foreigners, however, were still banned from setting foot on Chinese soil unless they came for tributary missions. ${ }^{\text {roo }}$ Now the multilateral inter-regional trade, in which Chinese manufactures (silk, porcelain) along with tea and grain were the leading trade goods, inflated. As Brook writes:

The trade was organized along two main routes, both starting at Moon Harbor and Quanzhou. The Eastern Sea (Dongyang) route headed for the lee of Taiwan; there one spur ran north to Japan, but the main flow of trade went south to the Philippines, down through the Moluccas (the Spice Islands to the Europeans) and west to Java. The Western Sea (Xiyang) route hugged the coast of the mainland past Vietnam, across the Gulf of Thailand, and on to Malacca. ${ }^{\text {Ior }}$

Brook's description here originates in Ming contemporary writings, including Zhang Xie's 張隻 (I574-I640) survey of maritime trade in the early seventeenth century, the Dongxi yang kao 東西洋考 (Study of the Eastern and Western Seas), ${ }^{102}$ which along with other volumes authored around the same time provide information about the extent to which China was involved in the South China Sea world economy. ${ }^{\text {I03 }}$ Brook has also written about another singularly important source that shows how information about seafaring outside China's borders did not get lost after the fifteenth-century voyages of Zheng He. The 'Laud rutter', or Shunfeng xiangsong 順風相送 (Dispatched on favorable winds), is a navigator's guide (in words, not in maps) giving compass bearings for sea routes that connected China to Japan, the Philippines, other locations in Southeast Asia, ports in the Indian Ocean, and westwards to the mouth of the Persian Gulf. ${ }^{104}$ This work, presented in I639 to Oxford University's Bodleian Library by Archbishop Laud who had received it from a visiting Jesuit, probably has its origins in another rutter, Duhai fangcheng 渡海方 程 (Mileage of ocean crossings), printed in 1537. ${ }^{\text {I05 }}$ Brook argues that the existence of the Laud rutter demonstrates Chinese people "actively engaged in weaving the commercial

\footnotetext{
98 Brook 2008, p. I64.

99 Brook 2010, p. 224; Andrade 2009, p. 5.

Ioo Chang 2006, p. 23. See also Brook 2008, Ch. 4 'Geography Lessons’ for an account of what happened to a group of shipwrecked foreigners who reached the Fujian coast and how the Chinese authorities severely dealt with them.

IOI Brook 20IO, p. 228.

IO2 Brook 20IO, p. 228.

I03 Chang 2006, pp. I8-22 briefly discusses some of these other works.

IO4 Brook 20IO, pp. 2I6-I7.

I05 T'ien I982.
} 
threads that were tying the Ming to the rest of the world and by so doing, creating the conditions for the rise of capitalistic enterprise in Europe.” ${ }^{\text {о } 6}$ The Laud rutter is complemented by another Chinese source also located in the Bodleian Library, 'Mr. Selden's Map'. ${ }^{\text {I07 This }}$ map was originally made for a Chinese merchant who lived in Java around I607 but was seized by a foreign 'merchant-pirate' and fell eventually into the possession of Selden, an English lawyer interested in Anglo-Dutch naval rivalries and who bequeathed it, among his other scholarly possessions, to the Bodleian Library. What makes the map so valuable for understanding Ming maritime China is the web of lines connecting points from the Fujian coast to all places around the South China Sea-in other words, evidence of Ming traders weaving their commercial webs to connect to the rest of the world. ${ }^{\text {ro8 }}$

Scholars tracing Chinese trading routes of the late sixteenth and early seventeenth centuries have shown that the most popular port was Luzon (Manila), for which the government issued sixteen permits per year. Other favorite destinations included Banten, Palembang, Siam, Tongking, Cambodia, Sunda, Melaka, Hue (Vietnam), and northern Taiwan. ${ }^{109}$ But this was probably only the tip of an iceberg-Spanish records indicate many more Chinese ships arrived in Manila than the official numbers allowed, and Japanese documents also show that scores of Chinese vessels went to Nagasaki even though no licenses were issued for trade there. ${ }^{\text {II }}$

The continuation of the maritime prohibition against trade with Japan originated out of the violence that ensued in I 523 when two rival noble Japanese families (daimyō 大名) sent 'official' tribute delegations to Ningbo at the same time. ${ }^{\text {II }}$ Thereafter, the Ming authorities, who had been vigilant over the situation of Japan's civil war (I467-I573) for years, allowed two more missions, but by mid-century refused Japanese attempts at tribute altogether. ${ }^{\text {II } 2}$ The opening of silver mines in Japan during the I530s and I540s put extra pressure on China to allow less regulated and more multi-dimensional trade. ${ }^{\text {II } 3}$ That China refused to do so meant that the daimyo, in need of funding for their armies, had to find other means by which to enrich themselves. The sale of precious Chinese silk (obtained via tribute trade) at ten times its original price was no longer an option. The mid-century smuggling and piracy along the Chinese coast helped, but as Tonio Andrade explains, it was the Japanese traders in Southeast Asia that proved most effective. Once (c. I500) the Japanese adapted their flat-bottomed ships with inadequate sails to Chinese designs that made them faster and more seaworthy, ${ }^{\text {II } 4}$ they began to venture to Southeast Asia. Japanese communities sprouted in Vietnam, Cambodia, Siam, and the Philippines. ${ }^{\text {II5 }}$ It was in these

\footnotetext{
I06 Brook 20Io, p. 2I7.

I07 Brook 20I3b.

I08 Brook 20I0, p. 2 I7.

Io9 Andrade 2009, p. 5.

I IO Andrade 2009, p. 5.

I I Rawski 20I0, p. 55.

I 2 Elisonas I99I, p. 229.

II3 Wilson 2009, p. 258.

II4 Andrade 2009, p. 7.

II5 Wray 2005.
} 
locations that Chinese and Japanese traders met each other and exchanged porcelains and silks for silver. Also both groups did their exchanges via European intermediaries. ${ }^{\text {II } 6}$

The first Europeans to gain a foothold in the South Sea world economy were the Portuguese, who wormed their way into tributary status by bribing a Guangzhou official and attracting the Chinese authorities' attention by helping them to expel pirates. In recognition for their efforts, the Ming government in 557 granted the Portuguese the right of abode on Macao, sufficiently nearby the silk markets of South China. ${ }^{\text {II }}$ The Portuguese started a three-way operation between Macao, Japan, and other Asian countries. Sailing each summer from Macao and arriving in Japan twelve to thirty days later, they took the silk in carracks or naos and exchanged the commodity for Japanese silver, and then returned in November or December to southern China. By I57I, the Portuguese also acquired a trade station in Nagasaki. While the Portuguese had made their way to Asia via Africa and through the Indian Ocean, the Spanish approached East Asia from the opposite direction. From South and Middle America where they exported the silver they had mined there, they made their way to the Philippines. In I559 they conquered these islands and in I57 I established the city of Manila on Luzon island, which hitherto had been dominated by Muslim merchants who actively traded with Chinese and Japanese dealers there. Thereafter, Chinese, Japanese, Portuguese, and Spaniards vied with each other for control of Macao, Taiwan, and the Philippines. ${ }^{\text {I } 8}$ The third major European force to arrive in East Asia were the Dutch, whose government granted the Dutch East Asian Company the legal rights to wage war and make treaties with foreign powers. ${ }^{\text {I } 9}$ They first attempted a stronghold in East Asia by building a fort (Casteel Zeelandia) outside Anping 安平 (Tainan) on the western coast of Taiwan, which they used as a base for trade in the region. The Dutch were a formidable enemy of both the Portuguese and Spanish in Asia, and elsewhere. ${ }^{\mathrm{I20}}$ Soon thereafter the Spanish also built forts on Taiwan, which only exacerbated the tensions between the two powers. ${ }^{\mathrm{I} 2 \mathrm{I}}$

The silver that Chinese merchants shipped to the South China coast from Manila had become a necessity in the Chinese economy. With the collapse of China's paper money system and the growth of its commercial economy in the sixteenth century, there was ever greater demand for the metal as the basis for exchange. ${ }^{122}$ From the European point of view silver was also the perfect exchange commodity-it could be traded for

I 6 Korea was also an option for the Japanese to obtain Chinese goods, but in the sixteenth century that country, in response to Japanese piracy along its coast, also put more and more restrictions on that trade. See Rawski 20I0, p. 56; Elisonas I99I, pp. 240-46.

II7 Andrade 2009, pp. 9-IO; Asano 2005, p. I88. On the complexity of early sixteenth-century Ming government debates over the Portuguese trade engagement in South China, see Brook 20I3a. For official accounts of these debates in the Mingshi, see Fisher 2000.

II8 Asano 2005, p. I89.

II9 The Dutch East India Company was not financed by taxes, but by investors. And because the Dutch monarchy sanctioned the Company officially, Dutch merchants could also serve as official representatives in dealings with foreign powers. On the Company structure, see Brook 2008, pp. I5-I8.

I 20 Asano 2005, p. I89; Andrade 2009, p. II.

I 2 I Asano 2005, p. I90.

I 22 Brook 2008, p. I60. There is a tremendous amount of secondary literature on China's demand for silver. See Von Glahn 1996; Atwell 1998; Flynn and Giraldez I995. 
gold (at three times the rate in China) and arbitrage profits were high. ${ }^{123}$ The higher value of silver in the Chinese market allowed foreign traders to make profits on selling Chinese goods in their home markets. ${ }^{\mathrm{I}} 4$ About "half the silver production accounted for in the world between I500 and I800' ended up in China, where it supported, even if it did not cause, the silver monetarization of the Ming economy." ${ }^{25}$ It should be emphasized that it was the lure of Chinese goods that attracted foreign traders in the first place. As Brook remarks: "Attributing the explosion of [Ming] wealth to the arrival of ... South American silver reverses cause and effect." ${ }^{26}$ In I597 it was estimated that nearly thirty-five metric tons of silver (more than 8.5 million taels) entered China via Manila. ${ }^{\mathrm{I} 7}$ This sum, it is likely, amounted to more than twice the entire Ming tax revenue for that same year. ${ }^{\mathrm{I} 28}$

The foreign trade catalyzed commercial expansion along the southeast coast, and via domestic trade networks, suppliers scrambled to provide Fujian and Guangdong merchants with exports. ${ }^{\mathrm{I} 9}$ Demand raised prices in China, created fortunes, and led to significant changes in Chinese culture and society. The dichotomy of extravagance and frugality, of luxury and poverty, which had ever been present in Chinese society now sharpened to a greater degree. ${ }^{\text {I30 }}$ Entrance into elite social circles required even greater knowledge of refinement, ${ }^{\mathrm{I} 3 \mathrm{I}}$ while penury for those not lucky enough to partake of the new riches intensified. The sixteenth-century China saw writings by literati of the miseries and despair of the poor; Huang Jishui 黃姬水 (I509-I574) wrote in his Pinshi zhuan 貧士傳 (Biographical sketches of poverty-stricken scholars) not only about the suffering by the literati elite but also of the common people whose fight against hunger, sickness, and homeless destitution was depicted by the great painter Zhou Chen 周臣 (I460-I536) in his series of portraits 'The Vagrants' (Liumin 流民). ${ }^{\mathrm{I} 32}$

In conclusion, the Ming 'open seas' policy may be viewed as a "reluctant recognition" of the status quo rather than a reversion to Song and Yuan government policies toward maritime trade. ${ }^{133}$ Chinese who engaged in overseas commerce were still the object of suspicion, and rarely received recognition or support. So, when in I603 Spanish officials massacred 20,000 residents in Manila, the Ming government did not retaliate. And the same occurred in I639 when another group of Chinese in the Philippines revolted against

\footnotetext{
I23 Brook 20Io, p. 230.

I24 Brook I998, p. 208.

I25 Rawski 20ı, p. 57 citing Von Glahn I996, pp. I39-40.

I26 Brook 20I0, p. 23I. See also Brook I998, p. I2 on his disagreement with Adshead I995 on this point.

I27 Wilson 2009, p. 264 based on Atwell I982.

I 28 Ray Huang I998, p. I48 states that the annual revenue of the Ming state was "well below 3 million taels."

I 29 Brook I998, pp. 205-06 quotes a Spanish account of the full range of Chinese goods available in Manila which ranged far beyond silks and porcelains, including foodstuffs. New World food crops were also an important item which the Chinese traders took back home from Manila. See Mazumdar I999.

I30 Zurndorfer 2002.

I3I Clunas I99I.

I32 Zurndorfer 2002, p. I6I; see also Levenson I99I, pp. 444-45 for reproductions of Zhou Chen's illustrations. I33 Andrade 2009, p. 6.
} 
their Spanish overlords. ${ }^{\mathrm{I}} 34$ As Tonio Andrade concludes, the Ming authorities may have tolerated overseas trade but they did not foster it. Moreover, despite the great wealth the imported silver bolstered within China, the Ming government did not transform its political economy and create new fiscal institutions to exploit overseas commerce. ${ }^{135}$ The state was not prepared to penetrate the maritime commercial sector. ${ }^{136}$ Where the Ming government did exert its power and influence, however, was in the realm of maritime defense which, as recent scholarship shows, prompted a number of Ming authorities to consider capitalizing on the imported silver to pay for rising military expenditures.

\section{MING NAVAL POWER AND THE SIXTEENTH/ SEVENTEENTH-CENTURY CRISES}

Just as many historians view Ming China's maritime history as one of glory and then stagnation beginning with the end of Zheng He's voyages, they also underestimate the changing circumstances of Ming naval military power. ${ }^{137}$ Andrew Wilson's recent study persuasively argues that conventional historiography, both by East Asian and Western scholars, has overstated later Ming neglect of the military maritime domain. Long after the fifteenth-century expeditions, the state maintained large numbers of naval vessels for counter-piracy and coastal defense missions-in other words, maritime security remained a government priority. ${ }^{\mathrm{r} 38}$ One need only glance at the late Ming writings that make obvious the size and capabilities of both merchant and naval fleets for this to be apparent. As Wilson notes, Ming contemporaries such as Li Zhaoxiang 李昭祥 (I537I553), who served as executive director of the imperial shipyards at Nanjing and compiled the Longjiang chuanchang zhi 龍江船廠志 (Records of the shipbuilding yards on the Dragon River) which contains descriptions and dimensions of the large vessels built there, ${ }^{\mathrm{I} 39}$ or Mao Yuanyi 茅元儀 (I594-I64I), who wrote the Wubeizhi 武備志 (Treatise on armament technology, I62 I), ${ }^{140}$ exemplify the drive behind Ming military defense efforts in the latter part of the dynasty. Also relevant here is Zheng Ruozeng’s 鄭若曾 (I505-I580) Chouhai tubian 籌海圖編 (Gazetteer of coastal defense, I562), which was a compilation of technical accounts of the development and application of military technologies, illustrations, and maps, along with extensive descriptions of actual battles and campaigns. ${ }^{\text {I4I }}$ These works and others attest to the fact that the Ming military establishment in the late sixteenth

I34 Brook 20Io, p. 23 I.

I 35 In contrast to the eighteenth-century 'Canton system' in which the Qing government did have the intention to exploit the trade there. See Will i999, p. 358.

I36 Ming China's 'laissez-faire economic policy' is quite the opposite of contemporaneous maritime European states' program to open new markets worldwide. See Wilson 2009, p. 255.

I37 Wilson 2009, p. 238.

I38 Wilson 2009, p. 239.

I39 Wilson 2009, p. 240; DMB, pp. 804-5. Ptak 2003b's close examination of Li Zhaoxiang's text leads him to conclude that Ming China's acquisition of naval technological knowledge in the early sixteenth century came not only through the Portuguese but also via innovations made in Southeast Asia.

I40 Wilson 2009, p. 240; DMB, pp. I053-54.

I4I $D M B$, pp. 204-8. 
century was a dynamic and vital component of the government. Too often, modern historians have followed the Jesuit Matteo Ricci's (I552-I6IO) exhortation to idealize Confucian passivity, and thereby they ignore or even denigrate the importance of war in Ming history. ${ }^{\mathrm{I} 42}$

Both Wilson and Kenneth Swope consider the two major problems that confronted the Ming authorities during the second half of the sixteenth century: coastal piracy and the Japanese invasion of Korea, known as the Imjin Waeran 壬辰倭亂 (I592-I598). ${ }^{\text {I43 }}$ With regard to the first difficulty, whatever advantages the maritime prohibitions had fostered in terms of prudence and economy, by the mid-sixteenth century security crises compelled both a reappraisal of that policy (which was accomplished in 1567) and also a new means of dealing with defense along the littoral. Moreover, as Swope relates in his important study of the Imjin Waeran, these military innovations in the suppression of piracy became the basis of Ming strategy in the Korea conflict. ${ }^{144}$ For example, the tactics of the man-in-charge of coastal security at the time of the second piracy upsurge, Qi Jiguang 戚繼光 (I528-I588), were integral to both Chinese and Korean resistance in that war. ${ }^{\mathrm{I45}}$ Qi realized that the best response to pirate raiding parties, which were often led and trained by Japanese warriors who emphasized cohesive small unit actions and close combat, was to do the same. Thus, he revamped the Ming hereditary military wei-suo 衛所 (brigades and battalions) system first put in place by Zhu Yuanzhang in the I370s. ${ }^{146}$ This coastal defense command structure, which was spread out all along the littoral but staffed and equipped according to terrain and population density, had been largely preventative-designed to deny key areas to pirate infestation. During the relatively quiet period of the fifteenth century, this framework proved sufficient. ${ }^{\mathrm{I} 47}$

But the wokou predations of the sixteenth century required inventive solutions. Qi Jiguang recruited private soldiers who were often locals with a vested interest in regional defense, instructed them how to use weapons, combined arms formations to counter landing parties, and eventually deployed large numbers of naval vessels of which almost all were armed with cannon. ${ }^{\mathrm{I} 8}$ Contemporary observers agreed that what made his military accomplishment so unique was the way Qi trained his soldiers and employed them in new kinds of tactical formations. He compiled training manuals that gave detailed instructions in the use of small-group tactics, psychological warfare, and repetitive drilling; when the

I42 Swope 2009, p. I7 cites Jacques Gernet's statement that the Ming armies were "the refuse dump of society and consisted of idlers, rascals, jailbirds, and highwaymen" (p. 43I), in his book The History of Chinese Civilization (I982), as indicative of this tendency.

I43 Wilson 2009, pp. 264-68; Swope 2009, p. 5 explains that Imjin is the Korean designation for the year I 592, and Waeran for Japanese. The translation from Korean means "Japanese calamity of I 592 ." For the latest studies of this important war, see the essays in Lewis 2014.

I44 Swope's 2009 book is the first academic study of this war that utilizes relevant sources in Chinese, Japanese, and Korean. Hawley 2005 is based largely on Korean language sources, while that by Turnbull 2002 employs mainly Japanese language publications.

I45 See Swope 2009, p. I9. On Koreans adapting Qi Jiguang’s military strategy, see Andrade et al. 20I4, pp. 63-70. See also Zurndorfer 2014 .

I46 Wilson 2009, pp. 247-48.

I47 Wilson 2009, p. 255.

I48 Wilson 2009, pp. 260-6I; Wilson 2009, p. 282, n. 70 writes about how the Chinese accession of Macao to the Portuguese may have been a reward for their military help against the wokou. 
war broke out, these handbooks were widely disseminated in Korea. ${ }^{\mathrm{I} 99}$ Qi Jiguang is also credited with learning to use amphibious warfare to expel pirates from their offshore bases and to intercept raiding parties at sea. ${ }^{150}$ Even after the wokou crises died down, the Ming government remained vigilant, and encouraged administrators to spread information about how ordinary people could resist attack. The eminent scholar official Lü Kun 吕坤 (I536I6I8) compiled a handbook Shoucheng jiuming 守城救命 (Saving lives while defending a city; 1607 preface) that informed a general readership not only about how to protect themselves against pirates and bandits, but also included descriptions of small arms. ${ }^{15 \mathrm{I}}$

Such advancements in military strategy and local security by the close of the sixteenth century meant that China was not "a moribund state tottering toward an inevitable demise," as Ray Huang in his influential book 1587: The Year of No Significance aimed to show. ${ }^{152}$ The portrait of the Wanli 萬曆 Emperor (r. I573-I620) that Huang created more than thirty years ago is also at variance with the facts. By the last decade of the sixteenth century, this emperor was waging 'three punitive campaigns': a crusade to eradicate an aboriginal chieftain in southwest China; an offensive to quash a mutiny of SinoMongolian troops in the northwest; and on the Korean peninsula, the Imjin Waeran. This invasion of Korea was led by Toyotomi Hideyoshi 豊臣 秀吉 (I536-I598), who became Japan's hegemon around I590 after uniting all of Japan under his rulership. ${ }^{\text {I53 }}$ Swope attributes Chinese success in this conflict to Emperor Wanli himself, who "was very interested in and devoted to maintaining Ming military supremacy in Asia." ${ }^{54}$

In May I592, over I60,000 Japanese troops landed at Pusan (Korea) and fought the

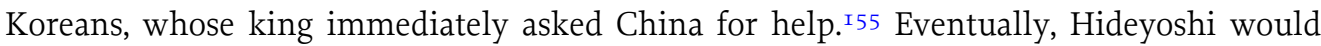
mobilize half a million troops and 700 ships, which meant in terms of men and material that this conflict was five to ten times the scale of the Spanish Armada of I588. ${ }^{156}$ Since Hideyoshi's intention was to use Korea as a springboard for the eventual conquest of Ming China, the Chinese intervention was motivated both by the desire to defend its tribute client Korea and to save the dynasty. Hideyoshi's overall goal may have been to solve Japan's economic problems by linking trade in Asia through Japanese ports, including Osaka. ${ }^{157}$ This incentive is also confirmed by his attempts during the war to enlist the support of surrounding states, and even that of Spanish and Portuguese officials, for his cause. ${ }^{158}$ Over 100,000 Chinese troops came to fight on Korea's side; after six years of

\footnotetext{
I49 Swope 2009, p. I9. Andrade 20I4, pp. 6I-65.

I50 Wilson 2009, p. 26I.

I5I Zurndorfer 20I4, pp. 207-9.

I52 See the critique of Huang's I98I book by Swope (2009), p. I6.

I53 An important new compilation of studies on the Imjin Waeren is Lewis 2014.

I54 Swope 2009, p. I6.

I55 Swope 2005, p. 4I.

I56 Swope 2005, p. I3; Hawley 2005, p. ii.

I57 Swope 2009, p. 63.

I58 Swope 2009, p. 6. See also the important article by Nakajima 2008 which narrates and analyses efforts by one of Hideyoshi's henchmen Katō Kiyomasa 加藤 清正 to establish in I593 a trading network linking Fujian, Kyushu, and Southeast Asia. Also relevant is Clulow 2013.
} 
war, the Japanese retreated, Hideyoshi died, and peace returned to East Asia. Although the small contingent of 3,000 soldiers the Ming first sent to Korea in summer of I592 was almost entirely annihilated, ${ }^{159}$ the Chinese government quickly sprang into action and organized an all-out defense that successfully routed the enemy.

Swope's ground-breaking examination attributes Ming victory in the campaigns against Japan to a combination of excellent leadership, mobilization, and innovation that included the adoption of firearms and artillery. He has traced the "multi-directional" flows of military technology before, during, and after the war. ${ }^{160}$ He notes that the Chinese had been adopting Portuguese military technology already in the I520s-the folangji 佛郎機, a type of culverin (long-range cannon), was used on Ming ships. According to Swope, "a typical Fujianese warship of the late sixteenth century carried one heavy cannon, one mortar, six culverins, three falconets, and sixty fire lances, easily outclassing anything the Japanese put to sea." ${ }^{61}$ Also, Kenneth Chase's study of Ming firearms underscores how the Chinese government encouraged the import of superior foreign armory, including a variety of muskets. ${ }^{162}$ Wilson's investigation shows that Ming commanders early in the war realized they held the advantage in naval warfare, and that the Japanese, with their knowledge of handheld weapons and light artillery, were more proficient at land warfare. ${ }^{\mathrm{I}} 3 \mathrm{~T}$ This is an ironic observation, given that Japan is an island nation and China a continental power. Moreover, Japanese naval weakness was crucial for China's funding this war. That Hideyoshi was unable to deploy naval forces to expand the confrontation to include attacks on China's northern and southern ports, or harass Chinese maritime trade, meant that the flow of silver to China from Southeast Asia was not disrupted.

The Wanli Emperor financed China's participation in this war through fiscal expedients aimed to tax those persons in possession of silver, which signified in the long run that he was tapping into the riches of foreign trade. In 1596 he ordered court eunuchs, under the guise of mining intendants, to demand silver bullion directly from local landed elites and merchants. ${ }^{164}$ This emergency measure was extremely unpopular and underlined the tensions between the Emperor and elite scholar-officials. During the Imjin Waeren, the monarch's efforts to access specie for war finance put him up against these persons who manned the imperial bureaucracy and opposed any increase in the state's extraction capabilities. ${ }^{165}$ In 1599, the Emperor widened the scale of the eunuchs' power to include their supervision of major ports where they were expected to work with local civil officials to collect commercial taxes. ${ }^{166}$ Wanli's efforts to "insinuate the state into the maritime

\footnotetext{
I59 Swope 2009, pp. I23-25.

I60 Swope 2005, pp. I3-I4 notes that after the war there was a dissemination of firearms technology from Japan to China via captured Japanese prisoners, and the transmission of Dutch knowledge of cannon making to the Koreans.

I6I Swope 2009, p. 78.

I62 Chase 2003, pp. I50-7I. Andrade 2015 demonstrates how the import of Portuguese military technology adapted to Chinese needs inspired in "a military technology revolution" in East Asia.

I63 Wilson 2009, p. 267.

I64 Huang I988, pp. 530-32.

I65 Wilson 2009, p. 266.

I66 Huang I988, pp. 530-3I.
} 
sector" were opposed by elites living in coastal zones, who had the most to lose by government penetration into the commercial or maritime economies. ${ }^{\mathrm{I}}{ }^{67}$ In the first decade of the seventeenth century, Wanli's adversaries, namely members of the Donglin 東林 faction, made near impossible any innovations in fiscal policy or a forward-looking military program. Wilson identifies Donglin's southern membership "who wanted to keep the state out of the southern economy" as the greatest impediment to the upkeep of the military advances that the Ming had achieved during the I590s. $^{\text {I68 }}$

\section{THE END OF AN ERA}

By the r630s the Ming government had become revenue-poor and militarily weak, while ruling over a domestic economy that was both huge and directly tied to the immense global movement of wealth. Consequently, as the court came to turn more and more of its attention to defense along the northern borders in the struggle against the Manchus and their allies, regional forces began to gain the upper hand. Security all along the coast began to lapse as military elites shifted their political allegiance-for example, the I63I-I633 mutiny led by Kong Youde 孔有德 (d. I657) against the Ming on the Shandong peninsula signified that locale's increasing integration into the large regional space of the Bohai 渤海 littoral. ${ }^{169}$ Already in the I620s, the response of the government was to invest regional officials with ever more authority over maritime affairs, which allowed the emergence of one of the most powerful commercial/military families to gain power over the Ming state, i.e. the Zheng family.

The founder of the family, Zheng Zhilong 鄭芝龍 (I604?-I66r?), one-time pirate, merchant, and official, was a native Fujianese raised in the Portuguese enclave of Macao where he was baptized a Catholic. ${ }^{170} \mathrm{He}$ began his pirate/merchant career in southern Japan under the tutelage of the Chinese headman at the Japanese port of Hirado 平戸, Li Dan 李旦 (d. I625), who led the illicit Hirado-Xiamen trade. After Li's death, Zheng struggled to take over Li's business interests and enlisted Dutch traders who had settled in Taiwan to help him destroy the hold that the Portuguese and Spanish had on regional trade. At this point, Zheng Zhilong served as both a privateer attacking Iberian shipping with Dutch support and as a trader and diplomat serving the Ming government. By the late I620s, Zheng dominated the trade between Taiwan and Fujian, and the Ming government rewarded him with an official title, that of 'Patrolling Admiral'. According to Andrade, Zheng Zhilong was something of a 'noble robber', a seaborne Robin Hood who was careful to avoid violence against common people, ${ }^{\text {I7I }}$ but it was Zheng Zhilong's role as a commander of counter-piracy in the Taiwan straits area that made him most remarkable. As

I67 Rawski 20I0, p. 55; Wilson 2009, pp. 267-68.

I68 Wilson 2009, p. 268. The Donglin movement established in I604 may be considered both an "ethical revitalization movement" and a national Confucian moral fellowship; see Dardess 2002, p. I. Adherents restored the Donglin Academy (Jiangsu province) which became a center of dissent for public affairs.

I69 Agnew 2009. The Bohai littoral includes the western coast of Korea.

I70 On Zheng Zhilong’s personal history, see Boxer I94I; Blussé I990; and Andrade 2009, pp. 45-48.

I7 I Andrade 2009, p. 46. 
Wilson writes, Zhang Zhilong was emblematic of the ambivalent place of China's maritime culture by the early decades of the seventeenth century. He summarizes:

In a sense, the Ming was outsourcing its maritime security. The trading post that the Dutch established in southern Taiwan as well as the cession of Macau to the Portuguese are also clear indicators that the Ming was perfectly content to outsource the management of trade entrepôts to non-Chinese, who then attracted Chinese merchants, sailors, and craftsmen to make these entrepôts economically viable. This was the case not only in Taiwan and Macau but also farther offshore in Manila, Malacca, Batavia, and Japan. The arrival of the Europeans in Asian waters had empowered the Chinese seagoing population, not displaced it. Zheng Zhilong is therefore indicative of the kind of economic and military power that one man was able to gather in this ungoverned space beyond China's shores, which explains the Ming's desire to co-opt him. ${ }^{172}$

In 1628 , Zheng established himself in the port of Yuegang with the aim of clearing the coast of pirates while he made a deal with the Dutch to enter a three-year trade agreement. ${ }^{173}$ Zheng would supply them with silks, sugar, ginger, and other goods in exchange for silver and spices at a fixed rate. ${ }^{174}$ It was through such 'wheeling and dealing' that Zheng Zhilong by the late I630s became the most powerful Chinese individual operating in Asian waters, a 'maritime prince'. On the eve of the Ming collapse he symbolized all that was wrong with what the maritime sector and naval defense had become. On the other hand, as Wilson argues, Zheng Zhilong and his descendants were also the last remnants of Ming maritime power. ${ }^{175}$ When everything else of the Ming state succumbed to the combination of peasant rebellions in the I630s and I640s and the Manchu invasion of I644, the last Ming loyalist remnants fought on from the sea and even got Taiwan rid of the Dutch. It would take the massive Qing naval and amphibious campaign against the island nearly forty years later, in I683, finally to extinguish the Ming and the maritime might of this dynasty.

\section{CONCLUDING REMARKS}

The closely intertwined relationship of Ming China's diplomatic, economic, and military history, as this article has demonstrated, manifests the significance of Chinese maritime borders as fluid and fluctuating sites of international exchange of money and material goods, technology transfer, military innovation, and not least, martial confrontation. Thus, the regime's maritime universe was far more significant than what the Braudelian Eastern Mediterranean concept of local commercial integration predicates. The dynamism of Chinese maritime history lay in the far-reaching extent to which the power and influence of the Ming state could be brought to bear upon other regional forces, though coastal

I72 Wilson 2009, p. 269.

I73 Wong I98I-83. Andrade 20II updates the story of the Dutch and their loss of Taiwan.

I74 Blussé I990, pp. 257-59.

I75 Wilson 2009, pp. 270-72. 
frontiers were never a consistent government priority. The success of the tribute trade system, even after Zheng He's voyages, rested in the continuing desirability of Chinese wares, such as silk and porcelain, which only increased over time. The tribute trade system also encompassed those countries around China that fostered a South Sea 'world system' in which the exchange of both goods and money flourished, but which the Ming government did not exploit in the form of taxes. In the course of the sixteenth century, as the conflict between persons supporting Chinese maritime restrictions and those favoring free trade heightened, and violence along the coast increased with illegal exchange and a growing belligerency among those living in the littoral, Ming maritime history entered a new phase. As militancy and discord along the sea borders continued to fester, regional officials gained ever more authority to regulate maritime affairs, which ultimately gave command to independent sub-contractors like Zheng Zhilong to exhort power. And thus, thanks to a century of naval and military innovation, it would take nearly forty years before the Qing dynasty could finally destroy the last vestiges of the Ming.

\section{REFERENCES}

\section{Abbreviations}

$D M B$ for Dictionary of Ming Biography, eds. Goodrich and Fang.

JESHO for Journal of the Economic and Social History of the Orient.

\section{Adshead I995}

Adshead, S. A. M. China in World History. 2nd edition, London: Macmillan, I995.

Agnew 2009

Agnew, Christopher. "Migrants and Mutineers: The Rebellion of Kong Youde and Seventeenth-Century Northeast Asia.” JESHO 52.3 (2009), pp. 505-4I.

Andaya 2006

Andaya, Barbara. “Oceans Unbounded: Transversing Asia across 'Area Studies'.” The Journal of Asian Studies 65.4 (2006), pp. 669-90.

Andrade 2015

Andrade, Tonio. "Cannibals with Cannons: The Sino-Portuguese Clashes of I52I-I522 and the Early Chinese Adoption of Western Guns.” Journal of Early Modern History I9.4 (2015), pp. 3 I I-35.

Andrade 20 I I

Andrade, Tonio. Lost Colony: The Untold Story of China's First Great Victory over the West. Princeton: Princeton University Press, 20 I I.

Andrade 2009

Andrade, Tonio. How Taiwan Became Chinese: Dutch, Spanish, and Han Colonization in the Seventeenth Century. New York: Columbia University Press; Gutenberg-e edition, 2009.

Andrade 2004

Andrade, Tonio. “The Company's Chinese Pirates: How the Dutch East India Company Tried to Lead a Coalition of Pirates to War against China, I62 I-I662." Journal of World History I5.4 (2004), pp. 4I5-44.

Andrade, Kang, and Cooper 2014

Andrade, Tonio, Hyeok Hweon Kang, and Kirsten Cooper. "A Korean Military Revolution: Parallel Military Innovations in East Asia and Europe.” Journal of World History 25.I (20I4), pp. 5I-84.

Antony 2003

Antony, Robert J. Like Froth Floating on the Sea: The World of Pirates and Seafarers in Late Imperial South China. Berkeley: Institute of East Asian Studies, University of California, 2003.

Arrighi, Hamashita, and Selden 2003

Arrighi, Giovanni, Takeshi Hamashita, and Mark Selden. "Introduction: The Rise of East Asia in Regional and World Historical Perspective.” In The Resurgence of East Asia: 500, I50 and 50 Year Perspectives, eds. Arrighi et al., pp. I-I6. London and New York: Routledge, 2003. 
Asano 2005

Asano Yasunori. "The Formation of a Japanocentric World Order." International Journal of Asian Studies 2.2 (2005), pp. I85-2I6.

Atwell 2002

Atwell, William S. "Time, Money, and the Weather: Ming China and the 'Great Depression' of the Mid-Fifteenth Century." Journal of Asian Studies 6I.I (2002), pp. 83-I I3.

Atwell I998

Atwell, William S. "Ming China and the Emerging World Economy, c.I470-I650." In The Cambridge History of China: Volume 8-The Ming Dynasty, I368-I644, Part 2, eds. Denis Twitchett and Frederick Mote, pp. 376-4I6. Cambridge: Cambridge University Press, I998.

Atwell I982

Atwell, William S. "International Bullion Flows and the Chinese Economy circa I530-I650.” Past and Present 95 (I982), pp. 68-90.

Barr I997

Barr, Allan. “The Wanli Context of the 'Courtesan's Jewel Box’ Story.” Harvard Journal of Asiatic Studies 57.I (I997), pp. I07-4I.

Bentley I 999

Bentley, Jerry. "Sea and Ocean Basins as Frameworks of Historical Analysis." The Geographical Review 89.2 (I999), pp. 2I5-24.

Blussé i 990

Blussé, Leonard. "Minnan jen or Cosmopolitan? The Rise of Cheng Chih-lung, Alias Nicolas Iquan.” In Development and Decline of Fukien Province in the I7th and I8th Centuries, ed. Eduard Vermeer, pp. $245-64$. Leiden: E.J. Brill, I990.

Boxer I94I

Boxer, Charles. "The Rise and Fall of Nicholas Iquan.” T'ien Hsia Monthly I I.5 (I94I), pp. 40 I-43.

Braudel I982-84

Braudel, Fernand. Civilization and Capitalism, I5th'I 8th Century, trans. Sian Reynolds. 3 vols. New York: Harper and Row, I982-84.

Braudel I976

Braudel, Fernand. The Mediterranean and the Mediterranean World in the Age of Philip II, trans. Sian Reynolds. 2 vols. New York: Harper and Row, I976.

Brook 20гза

Brook, Timothy. "Trade and Conflict in the South China Sea: Portugal and China, I5I4-23." In A Global History of Trade and Conflict since I500, eds. Lucia Coppolaro and Francine McKenzie, pp. 20-37. Basingstoke: Palgrave Macmillan, 2013.

Brook 20I3b

Brook, Timothy. Mr. Selden's Map of China: Decoding the Secrets of a Vanished Cartographer. New York: Bloomsbury Press, 2013.

Brook 2010

Brook, Timothy. The Troubled Empire: China in the Yuan and Ming Dynasties. Cambridge, MA: Harvard University Press, 2010.

Brook 2008

Brook, Timothy. Vermeer's Hat: The Seventeenth Century and the Dawn of the Global World. New York and London: Bloomsbury Press, 2008.

Brook I 998

Brook, Timothy. The Confusions of Pleasure: Commerce and Culture in Ming China. Berkeley: University of California Press, I998.

Chaffee 2006

Chaffee, John. "Diasporic Identities in the Historical Development of the Maritime Muslim Communities of Song-Yuan China.” JESHO 49.4 (2006), pp. 395-420.

Chang 2006

Chang, Pin-tsun. "The Sea as Arable Fields: A Mercantile Outlook on the Maritime Frontier of Late Ming China." In The Perception of Space in Traditional Chinese Sources, eds. Angela Schottenhammer and Roderich Ptak, pp. I7-26. Wiesbaden: Harrassowitz Verlag, 2006.

Chang I998

Chang, Pin-tsun. "The Formation of a Maritime Convention in Minnan (Southern Fujian), c. 900-I200.” In 
From the Mediterranean to the China Sea: Miscellaneous Notes, eds. Claude Guillot, Denys Lombard, and Roderich Ptak, pp. I43-55. Wiesbaden: Harrassowitz Verlag, I998.

Chang 1992

Chang Pin-tsun. "Maritime China in Historical Perspective." International Journal of Maritime History 4.2 (I992), pp. 239-55.

Chang I99I

Chang, Pin-tsun. "The First Chinese Diaspora in Southeast Asia in the Fifteenth Century." In Emporia, Commodities and Entrepreneurs in Asian Maritime Trade, c. I400-I750, eds. Roderich Ptak and Dietmar Rothermund, pp. 13-28. Stuttgart: Franz Steiner Verlag, I991.

Chang I990

Chang, Pin-tsun. "Maritime Trade and Local Economy in Late Ming Fukien." In Development and Decline of Fukien Province in the I7th and I8th Centuries, ed. Eduard Vermeer, pp. 63-8I. Leiden: E.J. Brill, I990.

Chase 2003

Chase, Kenneth. Firearms: A Global History to I700. Cambridge: Cambridge University Press, 2003.

Chin 2010

Chin, James. "Merchants, Smugglers, and Pirates: Multinational Clandestine Trade on the South China Coast, I520-50." In Elusive Pirates, Pervasive Smugglers: Violence and Clandestine Trade in the Greater China Seas, ed. Robert J. Antony, pp. 43-57. Hong Kong: Hong Kong University Press, 2010.

Clark 2009

Clark, Hugh R. "Frontier Discourse and China's Maritime Frontier: China's Frontiers and the Encounter with the Sea through Early Imperial History." Journal of World History 20.I (2009), pp. I-33.

Clark 2006

Clark, Hugh R. "Maritime Diasporas in Asia before da Gama: An Introductory Commentary." JESHO 49.4 (2006), pp. 385-94.

Clark 200I

Clark, Hugh R. "Overseas Trade and Social Change in Quanzhou through the Song." In The Emporium of the World: Maritime Quanzhou, I000-I400, ed. Angela Schottenhammer, pp. 47-94. Leiden: Brill, 2001.

Clark I995

Clark, Hugh R. "Muslims and Hindus in the Culture and Morphology of Quanzhou from the Tenth to the Thirteenth Century." The Journal of World History 6.I (I995), pp. 49-74.

Clark r991

Clark, Hugh R. Community, Trade, and Networks: Southern Fujian Province from the Third to the Thirteenth Centuries. Cambridge: Cambridge University Press, I99r.

Clulow 2013

Clulow, Adam. "Like Lambs in Japan and Devils outside Their Land: Diplomacy, Violence, and Japanese Merchants in Southeast Asia." Journal of World History 24.2 (2013), pp. 335-58.

Clunas I99I

Clunas, Craig. Superfluous Things: Material Culture and Social Status in Early Modern China. Cambridge: Polity Press, I99I.

Dardess 2002

Dardess, John. Blood and History: The Donglin Faction and Its Repression 1620-1627. Honolulu: University of Hawai'i Press, 2002.

Deng 1997

Deng Gang. Chinese Maritime Activities and Socioeconomic Development, c. 2 Ioo B.C.-Igoo AD. Westport, CT: Greenwood Press, 1997.

$D M B$

Goodrich L. Carrington and Chaoying Fang, eds. Dictionary of Ming Biography. 2 vols. New York and London: Columbia University Press, 1976.

Dreyer 2007

Dreyer Edward J. Zheng He: China and the Oceans in the Early Ming Dynasty, I405-I433. New York: Pearson Longman, 2007.

Elisonas I991

Elisonas, Jurgis. “The Inseparable Trinity: Japan's Relations with China and Korea." In The Cambridge History of Japan, Volume 4: Early Modern Japan, ed. John Witney Hall, pp. 235-300. Cambridge: Cambridge University Press, I99I. 
Elvin 2002

Elvin, Mark. "Braudel and China." In Early Modern History and the Social Sciences: Testing the Limits of Braudel's Mediterranean, ed. John A. Marino, pp. 225-53. Kirksville, MO: Truman State University Press, 2002.

Evans 2002

Evans, Grant. "Between the Global and the Local There Are Regions, Culture Areas, and National States: A Review Article.” Journal of Southeast Asian Studies 33.I (2002), pp. I47-62.

Fairbank I982

Fairbank, John K. Chinabound: A Fifty-year Memoir. New York: Harper and Row, I982.

Fairbank I968

Fairbank John K. ed. The Chinese World Order: Traditional China's Foreign Relations. Cambridge, MA: Harvard University Press, I968.

Fernández-Armesto 2004

Fernández-Armesto, Felipe. "Maritime History and World History.” In Maritime History as World History, ed. Daniel Finamore, pp. 7-24. Gainesville: University Press of Florida, 2004.

Finamore 2004

Finamore, Daniel, ed. Maritime History as World History. Gainesville: University Press of Florida, 2004.

Findlay 2004

Findlay, Robert V. "How Not to (Re)Write World History: Gavin Menzies and the Chinese Discovery of America." The Journal of World History I 5.2 (2004), pp. 229-42.

Fisher 2000

Fisher, Carney T. "Portuguese as Seen by the Historians of the Qing Court." In Vasco da Gama and the Linking of Europe and Asia, eds. Anthony Disney and Emily Booth, pp. 307-2 I. Oxford: Oxford University Press, 2000.

Fitzpatrick 1992

Fitzpatrick, John. "The Middle Kingdom, the Middle Sea, and the Geographical Pivot of History." Review I5.3 (I992), pp. 477-522.

Flynn and Giraldez I995

Flynn, Dennis O. and Arturo Giraldez. "Arbitrage, China and World Trade in the Early Modern Period.” JESHO 38.4 (I 995), pp. 429-48.

Frank 1998

Frank, André Gunder. ReOrient: Global Economy in the Asian Age. Berkeley: University of California Press, I998. Gardella I985

Gardella, Robert. “The Maritime History of Late Imperial China: Observations on Current Concerns and Recent Research.” Late Imperial China 6.2 (I985), pp. 48-66.

Gaynor 2007

Gaynor, Jennifer L. "Maritime Ideologies and Ethnic Anomalies: Sea Space and the Structure of Subalternality in the Southeast Asian Littoral." In Seascapes: Maritime Histories, Littoral Cultures, and Transoceanic Exchanges, eds. Jerry H. Bentley, Renate Bridenthal, and Kären Wigen, pp. 53-68. Honolulu: University of Hawai'i Press, 2007.

Geiss I 988

Geiss, James. "The Chia-ching Reign, I522-I566." In The Cambridge History of China: Volume 7-The Ming Dynasty, 1368-1644, Part I, eds. Frederick Mote and Denis Twitchett, pp. 440-510. Cambridge: Cambridge University Press, I988.

Gipouloux 20I I

Gipouloux, François. The Asian Mediterranean: Port Cities and Trading Networks in China, Japan and Southeast Asia, I 3 th-2 Ist Century, trans. Jonathan Hall and Dianna Martin. Cheltenham, UK: Edward Elgar, 201 I.

Gipouloux 2009

Gipouloux, François. La Méditerranée asiatique: Villes portuaries et réseaux marchands en Chine, au Japon et en Asia du Sud-Est XVe-XXIe siècle. Paris: CNRS Éditions, 2009.

Goody 2006

Goody, Jack. The Theft of History. Cambridge: Cambridge University Press, 2006.

Grove and Selden 2008

Grove, Linda and Mark Selden. "Editors' Introduction: New Perspectives on China, East Asia, and the Global Economy.” In Hamashita Takeshi, China, East Asia, and the Global Economy: Regional and Historical Perspectives, pp. I-II. London and New York: Routledge, 2008. 
Guillot and Ptak 1998

Guillot, Claude and Roderich Ptak. "Preface." In From the Mediterranean to the China Sea: Miscellaneous Notes, eds. Claude Guillot, Denys Lombard, and Roderich Ptak, pp. vii-xii. Wiesbaden: Harrassowitz Verlag, I998.

Gunn 20II

Gunn, Geoffrey C. History without Borders: The Making of an Asian World Region, I000-I800. Hong Kong: Hong Kong University Press, 201 I.

Hall 2006

Hall, Kenneth R. "Multi-Dimensional Networking: Fifteenth-Century Indian Ocean Maritime Diaspora in Southeast Asian Perspective." JESHO 49.4 (2006), pp. 454-8I.

Hamashita 20II

Hamashita, Takeshi. "The Lidai Baoan and the Ryukyu Maritime Tributary Trade Network with China and Southeast Asia, the Fourteenth to Seventeenth Centuries." In Hamashita Takeshi, China, East Asia, and the Global Economy: Regional and Historical Perspectives, eds. Linda Grove and Mark Selden, pp. I07-29. Durham, NC: Duke University Press, 201 I.

Hamashita 2008a

Hamashita, Takeshi. "The Ryukyu Maritime Network from the Fourteenth to Eighteenth Centuries: China, Korea, Japan, and Southeast Asia." In Hamashita Takeshi, China, East Asia, and the Global Economy: Regional and Historical Perspectives, eds. Linda Grove and Mark Selden, pp. 57-84. London and New York: Routledge, 2008.

Hamashita 2008b

Hamashita, Takeshi. "The Tribute Trade System and Modern Asia," trans. Neil Burton and Christian Daniels. In Hamashita Takeshi, China, East Asia and the Global Economy: Regional and Historical Perspectives, eds. Linda Grove and Mark Selden, pp. I2-26. London and New York: Routledge, 2008.

Hamashita 2004

Hamashita, Takeshi. "Introduction to Intra-Asian Networks." International Journal of Asian Studies I.I (2004), p. 3.

Hamashita 1997

Hamashita, Takeshi. "The Intra-regional System in East Asia in Modern Times." In Network Power: Japan and Asia, eds. Peter J. Katzenstein and Takashi Shiraishi, pp. II3-35. Ithaca, NY: Cornell University Press, I997.

Hamashita I994

Hamashita, Takeshi. "The Tribute System and Modern Asia." In Japanese Industrialization and the Asian Economy, eds. A. J. Latham and Heita Kawakatsu, pp. 91-107. London and New York: Routledge, I994.

Hawley 2005

Hawley, Samuel. The Imjin War: Japan's Sixteenth-Century Invasion of Korea and Attempt to Conquer China. Seoul: The Royal Asiatic Society Korea Branch; Berkeley: The Institute of East Asian Studies, University of California, 2005.

Heng 2013

Heng, Derek. "Trans-Regionalism and Economic Co-dependency in the South China Sea: The Case of China and the Malay Region (Tenth to Fourteenth Centuries AD)." International History Review 35.3 (2013), pp. 486-510.

Hevia 1995

Hevia, James. Cherishing Men from Afar: Qing Guest Ritual and the Macartney Embassy. Durham, NC: Duke University Press, I995.

Hong 2010

Hong, Wontack. East Asian History: A Tripolar Approach. Seoul: Kudara International, 2010.

Huang 1998

Huang, Ray. "The Ming Fiscal Administration." In The Cambridge History of China: Volume 7-The Ming Dynasty, 1368-I644, Part II, eds. Frederick Mote and Denis Twitchett, pp. I06-7I. Cambridge: Cambridge University Press, 1998.

Huang 1988

Huang, Ray. "The Lung-ch'ing and Wan-li Reigns, I567-I620." In The Cambridge History of China: Volume 7-The Ming Dynasty, I368-I644, Part I, eds. Frederick Mote and Denis Twitchett, pp. 5 I I-84. Cambridge: Cambridge University Press, I 988.

Huang I98I

Huang, Ray. 1587: A Year of No Significance. New Haven: Yale University Press, I98I.

Kang 2010

Kang, David C. East Asia before the West: Five Centuries of Trade and Tribute. New York: Columbia University Press, 2010. 
Klein and Mackenthun 2004

Klein, Bernhard and Gesa Mackenthun, eds. Sea Changes: Historicizing the Ocean. London and New York: Routledge, 2004.

Kreiner 2001

Kreiner, Josef. "Ryūkyūan History in Comparative Perspective." In Ryūkyū in World History, ed. Josef Kreiner, pp. I-39. Bonn: Bier’sche Veerlagsanstalt, 200I.

Kuhn I997

Kuhn, Philip A. The Homeland: Thinking about the Chinese Overseas. Canberra: Australian National University, I997.

Kung and Ma 2014

Kung, James Kai-sing and Ma Chicheng. "Autarchy and the Rise and Fall of Piracy in Ming China." Journal of Economic History 74.2 (2014), pp. 509-34.

Kwee 2007

Kwee Hui Kian. "Pockets of Empire: Integrating the Studies of Social Organizations in Southeast China and Southeast Asia." Comparative Studies of South Asia, Africa and the Middle East 27.3 (2007), pp. 616-32.

Lai 1995

Lai Chi-kong. "The Historiography of Maritime China since c. 1975." Research in Maritime History 9 (1995), pp. 53-79.

Lee 1999

Lee, John. "Trade and Economy in Preindustrial East Asia, c. I500-c. I800: East Asia in the Age of Global Integration." Journal of Asian Studies 58.I (I999), pp. 2-26.

Levathes I994

Levathes, Louise. When China Ruled the Seas: The Treasure Fleet of the Dragon Throne, I405-I433. New York: Simon and Schuster, I994.

Levenson ig9r

Levenson, Jay A. Circa 1992: Art in the Age of Exploration. Washington: National Gallery of Art; New Haven: Yale University Press, I99I.

Lewis 2014

Lewis, James B., ed. The East Asian War, 1592-1598: International Relations, Violence and Memory. New York and London: Routledge, 2014.

Lewis and Wigen 1997

Lewis, Martin W. and Kären Wigen. The Myth of Continents: A Critique of Metageography. Berkeley: University of California Press, I997.

Li 2010

Li Kangying. The Ming Maritime Trade Policy in Transition, 1368 to 1567. Wiesbaden: Harrassowitz Verlag, 2010.

Li 2004

Li, Tana. "The Water Frontier: An Introduction." In Water Frontier: Commerce and Chinese in the Lower Mekong Region, I750-I880, eds. Nola Cooke and Li Tana, pp. I-I7. Lanham, MD: Rowman and Littlefield, 2004.

Lim 2010

Lim, Ivy Maria. Lineage Society on the Southeastern Coast of China: The Impact of Japanese Piracy in the I 6 th Century. Amherst, NY: Cambria Press, 2010.

Lockard 2010

Lockard, Craig A. "The Sea Common to All': Maritime Frontiers, Port Cities, and Chinese Traders in the Southeast Asian Age of Commerce, ca. I400-I750." Journal of World History 2I.2 (2010), pp. 219-47.

Lombard 1998 Lombard, Denys S. “Une autre Méditerranée dans le Sud-Est asiatique.” Hérodote 88 (1998), pp. I84-93.

Lombard I995

Lombard, Denys S. "Networks and Synchronisms in Southeast Asian History." Journal of Southeast Asian Studies 26.I (1995), pp. I0-I6.

Lombard 1990

Lombard, Denys S. Le carrefour javanais: Essai d'histoire globale. 3 vols. Paris: Editions de l'École des Hautes Études en Sciences Sociales, I990.

Manguin I993

Manguin, Pierre-Yves. "Trading Ships of the South China Sea: Shipbuilding Techniques and Their Role in the History of the Development of Asian Trade Networks." JESHO 36.2 (I993), pp. 253-80. 
Mazumdar 1999

Mazumdar, Sucheta. "The Impact of New World Food Crops on the Diet and Economy of China and India, r600-1900." In Food in Global History, ed. R. Grew, pp. 58-78. Boulder, CO: Westview Press, I999.

Menzies 2003

Menzies, Gavin. I42 I: The Year China Discovered America. New York: William Morrow, 2003.

Miller 2013

Miller, Peter N. "Introduction: The Sea Is the Land's Edge Also." In The Sea: Thalassography and Historiography, ed. Peter N. Miller, pp. I-26. Ann Arbor: University of Michigan Press, 2013.

Nakajima 2008

Nakajima, Gakushō. "The Invasion of Korea and Trade with Luzon: Katō Kiyomasa's Scheme of the Luzon Trade in the Late Sixteenth Century." In The East Asian 'Mediterranean': Maritime Crossroads of Culture, Commerce, and Human Migration, ed. Angela Schottenhammer, pp. I45-68. Wiesbaden: Harrassowitz Verlag, 2008.

Parry I974

Parry, J. H. The Discovery of the Sea. New York: Dial Press, I974; reissued Berkeley: University of California Press, I98I.

Perdue 2005

Perdue, Peter. "From Turfan to Taiwan: Trade and War on Two Chinese Frontiers." In Untaming the Frontier in Anthropology, Archaeology, and History, eds. Bradley J. Parker and Lars Rodeth, pp. 27-5I. Tucson: University of Arizona Press, 2005.

Perdue 2003

Perdue, Peter. "A Frontier View of Chineseness." In The Resurgence of East Asia: 500, I50 and 50 Year Perspectives, eds. Giovanni Arrighi, Takeshi Hamashita, and Mark Selden, pp. 5I-77. London and New York: Routledge, 2003.

Prazniak 2010

Prazniak, Roxann. "Menzies and the New Chinoiserie: Is Sinocentrism the Answer to Eurocentrism in Studies of Modernity?" The Medieval History Journal I3.I (2010), pp. II 5-30.

Ptak 2003a

Ptak, Roderich. "The Ryukyu Network in the Fifteenth and Early Sixteenth Centuries." Review of Culture 6 (2003), pp. 7-23.

Ptak 2003b

Ptak, Roderich. "The Wugongchuan (Centipede Ships) and the Portuguese." Review of Culture 5 (2003), pp. 73-83.

Ptak 200Ia

Ptak, Roderich. "International Symposium: 'China and Southeast Asia: Historical Interactions' (Hong Kong, I92I July 200I)." Archipel 62 (200I), pp. 3-6.

Ptak 200rb

Ptak, Roderich. "Quanzhou: At the Northern Edge of a Southeast Asian 'Mediterranean'.” In The Emporium of the World: Maritime Quanzhou, I000-I400, ed. Angela Schottenhammer, pp. 395-428. Leiden: Brill, $200 I$.

Ptak r998a

Ptak, Roderich. "Ming Maritime Trade to Southeast Asia, I368-1567: Visions of a 'System'." In From the Mediterranean to the China Sea: Miscellaneous Notes, eds. Claude Guillot, Denys Lombard, and Roderich Ptak, pp. I57-9I. Wiesbaden: Harrassowitz Verlag, 1998.

Ptak I998b

Ptak, Roderich. "International Symposium on the 'Asian Mediterranean' (Paris, 3-5 March I997)." Archipel 55 (I998), pp. I I-28.

Ptak I994

Ptak, Roderich. "Merchants and Maximisation: Notes on Chinese and Portuguese Entrepreneurship in Maritime Asia, c. I350-I600." In Maritime Asia: Profit Maximisation, Ethics and Trade Structure c. 1300-I800, eds. Karl Anton Sprengard and Roderich Ptak, pp. 29-59. Wiesbaden: Harrassowitz Verlag, I994.

Ptak and Lombard-Salmon 200I

Ptak, Roderich and Claudine Lombard-Salmon, eds. Hainan: de la Chine à l'Asie du Sud-Est/Von China nach Südostasien. Wiesbaden: Harrassowitz Verlag, 2001.

Rawski 2010

Rawski, Evelyn. "China's Relations with Korea and Japan during the Ming-Qing Transition.” Transactions of the International Conference of Eastern Studies 54 (2010), pp. 47-64.

Robinson 2010

Robinson, Kenneth. "Gavin Menzies, I42 I, and the Ryūkoku Kangnido World Map." Ming Studies 6I (20I0), pp. $56-70$. 
Robinson 2000

Robinson, Kenneth. "Centering the King of Chosǒn: Aspects of Korean Maritime Diplomacy, I392-I592." Journal of Asian Studies 59.I (2000), pp. I09-25.

Rozman I99I

Rozman, Gilbert. The East Asian Region: Confucian Heritage and Its Modern Adaptation. Princeton: Princeton University Press, I99I.

Schottenhammer 2008

Schottenhammer, Angela, ed. The East Asian 'Mediterranean': Maritime Crossroads of Culture, Commerce, and Human Migration. Wiesbaden: Harrassowitz Verlag, 2008.

Schottenhammer 2007

Schottenhammer, Angela, ed. The East Asian Maritime World I400-I800: Its Fabrics of Power and Dynamics of Exchanges. Wiesbaden: Harrassowitz Verlag, 2007.

Schottenhammer 2005

Schottenhammer, Angela, ed. Trade and Transfer across the East Asian 'Mediterranean'. Wiesbaden: Harrassowitz Verlag, 2005 .

Schottenhammer and Ptak 2006

Schottenhammer, Angela and Roderich Ptak, eds. The Perception of Space in Traditional Chinese Sources. Wiesbaden: Harrassowitz Verlag, 2006.

Sen 2006

Sen, Tansen. "The Formation of Chinese Maritime Networks to Southern Asia, I200-I450." JESHO 49.4 (2006), pp. $42 \mathrm{I}-53$.

So 2000

So, Billy (So Kee Long). Prosperity, Region, and Institutions in Maritime China: The South Fukien Pattern, 946-I368. Cambridge, MA: Harvard University Asia Center, 2000.

Soon 2008

Soon, Derek Heng Thiam. "Structures, Networks and Commercial Practices of Private Chinese Maritime Traders in Island Southeast Asia in the Early Second Millennium AD." International Journal of Maritime History 22 (2008), pp. 27-54.

Steinberg 2001

Steinberg, Philip E. The Social Construction of the Ocean. Cambridge: Cambridge University Press, $200 \mathrm{I}$.

Stuart-Fox 2003

Stuart-Fox, Martin. A Short History of China and Southeast Asia: Tribute, Trade and Influence. Crows Nest, Australia: Allen and Unwin, 2003.

Subrahmanyam I998

Subrahmanyam, Sanjay. "Notes of Circulation and Asymmetry in Two Mediterraneans, c. I40o-I80o." In From the Mediterranean to the China Sea: Miscellaneous Notes, eds. Claude Guillot, Denys Lombard, and Roderich Ptak, pp. 2 I-43. Wiesbaden: Harrassowitz Verlag, I998.

Subrahmanyam I994

Subrahmanyam, Sanjay. "Writing History 'Backwards': Southeast Asian History (and the Annales) at the Crossroads." Studies in History IO.I (I994), pp. I3 I-45.

Sutherland 2003

Sutherland, Heather. "Southeast Asian History and the Mediterranean Analogy." Journal of Southeast Asian Studies 34.I (2003), pp. I-20.

Swope 2009

Swope, Kenneth M. A Dragon's Head and Serpent's Tail: Ming China and the First Great East Asian War, I592I598. Norman, OK: University of Oklahoma Press, 2009.

Swope 2005

Swope, Kenneth M. "Crouching Tigers, Secret Weapons: Military Technology Employed during the Sino-Japanese War, I 592-I598." Journal of Military History 69 (2005), pp. I I-42.

Tagliacozzo I984

Tagliacozzo, Eric. "Underneath the Indian Ocean.” Journal of Asian Studies 67.3 (I984), pp. I039-46.

T'ien 1982

T’ien Ju-kang. “The First Printed Chinese Rutter: Duhai Fangcheng.” T'oung Pao 68 (I982), pp. 76-9o.

Tsai 1996

Tsai, Shih-shan Henry. Eunuchs in the Ming Dynasty. Albany, NY: State University of New York Press, I996. 
Tsiang I936

Tsiang Ting-fu (Jiang Dingfu). “China and European Expansion.” Politica 2 (I936), pp. I-I8.

Turnbull 2002

Turnbull, Stephen. Samurai Invasion: Japan's Korea War, I592-I598. London: Cassell, 2002.

Van Leur I955

Van Leur, Jacob C. "On the Eighteenth Century as a Category in Indonesian History." In Jacob C. van Leur, Indonesian Trade and Society: Essays on Asian Social and Economic History, pp. 269-89. The Hague and Bandung: W. van Hoeve Ltd., I955.

Vink 2007

Vink, Markus P. M. "Indian Ocean Studies and the 'New Thalassology'” Journal of Global History 2 (2007), pp. 4I-62.

Vogel I998

Vogel, Jaap. “J. C. van Leur, I908-I942: A Short Life in History.” In On the Eighteenth Century as a Category of Asian History: Van Leur in Retrospect, eds. Leonard Blussé and Femme Gaastra, pp. I3-38. Aldershot: Ashgate, I998.

Von Glahn

Von Glahn, Richard. Fountain of Fortune: Money and Monetary Policy in China, I000-I 700. Berkeley: University of California Press, I996.

Von Verschuer 2006

Von Verschuer, Charlotte. Across the Perilous Sea: Japanese Trade with China and Korea from the Seventh to the Sixteenth Centuries, trans. Kristen Lee Hunter. Ithaca, NY: Cornell University Press, 2006.

Wade 2008

Wade, Geoff. "Engaging the South: Ming China and Southeast Asia in the Fifteenth Century." JESHO 5 I.4 (2008), pp. 578-638.

Wade and Sun 2010

Wade, Geoff and Sun Laichen, eds. Southeast Asia in the Fifteenth Century: The China Factor. Hong Kong: Hong Kong University Press, 2010.

Wake 2004

Wake, Christopher. “The Myth of Zheng He’s Great Treasure Ships.” International Journal of Maritime History I6.I (2004), pp. 59-75.

Wakeman I993

Wakeman, Frederic. "Voyages." American Historical Review 98.I (I993), pp. I-I7.

Wang 2008

Wang, Gungwu. “The China Seas: Becoming an Enlarged Mediterranean.” In The East Asian 'Mediterranean': Maritime Crossroads of Culture, Commerce and Human Migration, ed. Angela Schottenhammer, pp. 7-22. Wiesbaden: Harrassowitz Verlag, 2008.

Wang I99I

Wang Gungwu. China and the Chinese Overseas. Singapore: Times Academic Press, I99I.

Wang 2002

Wang Yong. "Realistic and Fantastic Images of 'Dwarf Pirates': The Evolution of Ming Dynasty Perceptions of the Japanese.” In Sagacious Monks and Bloodthirsty Warriors: Chinese Views of Japan in the Ming-Qing Period, ed. Joshua Fogel, pp. I7-4I. Norwalk, CT: EastBridge, 2002.

Wang 2OII

Wang Yuan-kang. Harmony and War: Confucian Culture and Chinese Power Politics. New York: Columbia University Press, 20II.

Wiethoff I969

Wiethoff, Bodo. Chinas dritte Grenze: Der traditionelle chinesische Staat und der küstennahe Seeraum. Wiesbaden: Harrassowitz, I969.

Wigen 2007

Wigen, Kären. "Introduction.” In Seascapes: Maritime Histories, Littoral Cultures, and Transoceanic Exchanges, eds. Jerry H. Bentley, Renate Bridenthal, and Kären Wigen, pp. I-I8. Honolulu: University of Hawai'i Press, 2007.

Wigen 2006

Wigen, Kären. "Introduction: Oceans of History." American Historical Review I I I.3 (2006), pp. 7I 7-2 I.

Will I999

Will, Pierre-Étienne. "Discussions about the Market-Place and the Market Principle in Eighteenth-Century Guangdong.” In Zhongguo haiyang fazhan shi lunwen ji, ed. Tang Xiyong, pp. 323-89. Taipei: Academia Sinica, Sun Yat-sen Institute of Humanities and Social Sciences, 7, I999. 
Wills 1993

Wills, John E. "Maritime Asia I500-I800: The Interactive Emergence of European Domination." American Historical Review 98.I (I993), pp. 83-105.

Wills 1979

Wills, John E. "Maritime China from Wang Chih to Shih Lang: Themes in Peripheral History." In From Ming to Ch'ing: Conquest, Region, and Continuity in Seventeenth-Century China, eds. Jonathan Spence and John Wills, pp. 20I-38. New Haven: Yale University Press, 1979.

Wilson 2009

Wilson, Andrew R. "The Maritime Transformation of Ming China." In China Goes to Sea: Maritime Transformation in Comparative Perspective, eds. Andrew S. Erickson, Lyle J. Goldstein, and Carnes Lord, pp. 238-85. Annapolis, MD: Naval Institute Press, 2009.

Wolters 1982

Wolters, O. W. History, Culture, and Region in Southeast Asian Perspectives. Singapore: Institute of Southeast Asian Studies; rev. ed. I999, Ithaca, NY: Cornell Southeast Asian Program, I982.

Wong 2004

Wong, R. Bin. "Relationships between the Political Economies of Maritime and Agrarian China, 1750-1850." In Maritime China in Transition I750-I850, eds. Wang Gungwu and Ng Chin-keong, pp. I9-31. Wiesbaden: Harrassowitz Verlag, 2004.

Wong 2003

Wong, R. Bin. "Between Nation and World: Braudelian Regions in Asia." Review 26.I (2003), pp. I-45.

Wong 200I

Wong, R. Bin. "Entre monde et nation: les régions braudéliennes en Asie." Annales: Histoire, Sciences Sociales 56.I (200I), pp. 5-42.

Wong I98I-83

Wong Young-tsu. "Security and Warfare on the China Coast: The Taiwan Question in the Seventeenth Century." Monumenta Serica 35 (I98I-83), pp. I I I-96.

Wray 2005

Wray, William D. "The Seventeenth-century Japanese Diaspora: Questions of Boundary and Policy.” In Diaspora Entrepreneurial Networks: Four Centuries of History, eds. Ina Baghdiantz McCabe, Gelina Harlaftis, and Ioanna Pepelasis Minoglu, pp. 73-93. Oxford and New York: Berg, 2005.

Zhang 2009

Zhang Feng. "Rethinking the 'Tribute System': Broadening the Conceptual Horizon of Historical East Asian Politics." Chinese Journal of International Politics 2.4 (2009), pp. 545-74.

Zheng 200I

Zheng Zhenman. Family Lineage Organization and Social Change in Ming and Qing Fujian, trans. Michael Szonyi. Honolulu: University of Hawai'i Press, 200I.

Zurndorfer 2014

Zurndorfer, Harriet T. "Wanli China versus Hideyoshi's Japan: Rethinking China's Involvement in the Imjin Waeran.” In The East Asian War, I592-I598: International Relations, Violence and Memory, ed. James B. Lewis, pp. 197-235. New York and London: Routledge, 2014.

Zurndorfer $2004 \mathrm{a}$

Zurndorfer, Harriet T. "Tribute, Trade, and the Demise of the Chinese 'World Order' in Ming (I368-1644) and Qing (I644-I9II) China.” Leidschrift-Historisch Tijdschrift I8.3 (2004), pp. I7-32.

Zurndorfer $2004 \mathrm{~b}$

Zurndorfer, Harriet T. "Not Bound to China: Étienne Balazs, Fernand Braudel and the Politics of the Study of Chinese History in Post-War France." Past and Present I85 (2004), pp. I89-22 I.

Zurndorfer 2002

Zurndorfer, Harriet T. “Old and New Visions of Ming Society and Culture.” T'oung Pao 88 (2002), pp. I55-69. 